NBER WORKING PAPER SERIES

SWEDEN'S FISCAL FRAMEWORK AND MONETARY POLICY

Eric M. Leeper

Working Paper 24743

http://www.nber.org/papers/w24743

\author{
NATIONAL BUREAU OF ECONOMIC RESEARCH \\ 1050 Massachusetts Avenue \\ Cambridge, MA 02138 \\ June 2018
}

I thank Campbell Leith and Todd B. Walker for discussions and the Swedish Fiscal Council and Rachel Lee for detailed comments. I also thank Hannes Jagerstedt for patiently gathering data and explaining them to me. The views expressed herein are those of the author and do not necessarily reflect the views of the National Bureau of Economic Research.

NBER working papers are circulated for discussion and comment purposes. They have not been peer-reviewed or been subject to the review by the NBER Board of Directors that accompanies official NBER publications.

(C) 2018 by Eric M. Leeper. All rights reserved. Short sections of text, not to exceed two paragraphs, may be quoted without explicit permission provided that full credit, including () notice, is given to the source. 
Sweden's Fiscal Framework and Monetary Policy

Eric M. Leeper

NBER Working Paper No. 24743

June 2018

JEL No. E31,E52,E62

\section{ABSTRACT}

Basic economic reasoning tells us that monetary and fiscal policies always interact to jointly determine aggregate demand and the overall level of prices in the economy. This paper interprets Sweden's explicit monetary and fiscal frameworks in light of this reasoning, bringing recent Swedish inflation and interest-rate developments to bear on the interpretations. Theory and evidence raise the question of whether the two policy frameworks are mutually consistent.

Eric M. Leeper

Department of Economics

Indiana University

105 Wylie Hall

Bloomington, IN 47405

and Center for Applied Economics and Policy Research

and also NBER

eleeper@indiana.edu 


\title{
SWEden's Fiscal Framework And Monetary Policy*
}

\author{
Eric M. Leeper
}

\section{INTRODUCTION}

Basic economic reasoning tells us that monetary and fiscal policies necessarily interact in the short, medium, and long runs. These interactions jointly determine an economy's macroeconomic developments. This reasoning is completely general, independent of any particular economic model or view of how the economy operates.

Most countries' monetary and fiscal policy institutions, in contrast, are founded on the presumption that the two policies can and should operate independently of each other. This presumption underlies the creation of central banks that are given well-specified mandates to control inflation and stabilize the real economy and to operate in isolation from pressures that might emanate from fiscal authorities. Fiscal policy, meanwhile, is assigned the task of stabilizing debt — what is called "sustainable fiscal policy" — and often little else. Underlying this institutional construct are the beliefs that (i) fiscal policy has little, if any, impact on inflation; (ii) monetary policy has negligible fiscal consequences; and (iii) the single-minded fiscal pursuit of debt stabilization supports, rather than thwarts, the central bank's mandates. Sometimes, this institutional arrangement works. At other times, the arrangement leads to monetary and fiscal policies that are mutually inconsistent.

The presumption that policies can and should operate independently denies an essential fact about modern public finance: governments issue nominal bonds-bonds denominated in local currency - but bondholders care about the real value of those bonds. The real value comes from deflating nominal debt by the overall level of prices in the economy, something like the consumer price index. Because modern central banks aim to target the rate of change

\footnotetext{
*June 13, 2018. I thank Campbell Leith and Todd B. Walker for discussions and the Swedish Fiscal Council and Rachel Lee for detailed comments. I also thank Hannes Jägerstedt for patiently gathering data and explaining them to me.
} 
of the price level - the inflation rate - it is impossible to separate monetary and fiscal policy completely. And efforts to do so can create policy conflicts.

Recent Swedish monetary and fiscal actions illustrate the possibility of conflict. At a time when monetary policy has been aggressively expansionary in an effort to raise inflationnegative policy interest rates for three years, coupled with significant asset purchases that have produced a more than four-fold increase in the central bank's balance sheet from 2007 to $2017^{1}$ - fiscal policy has become more contractionary, with net lending moving from -1.6 percent of GDP in 2014 to 1.2 percent in the first two quarters of 2017. Fiscal policy has been deflationary when monetary policy has been inflationary.

Sweden is a fascinating case to study how monetary and fiscal policies interact to influence the aggregate economy. The country stands out for being explicit about the objectives and targets of macroeconomic policies. Sveriges Riksbank, Sweden's central bank, flexibly targets inflation at 2 percent, while the government currently pursues a medium-term netlending target of 1 percent of GDP. Explicitness makes Swedish policy behavior amenable to assessment, which is one goal of this article. I raise the possibility that the policy rule that Swedish fiscal authorities follow, particularly in recent years, may be at odds with the Riksbank's primary goal of targeting inflation.

\subsection{Targets vs. Rules}

Explicit policy targets are not sufficient to ensure effective policy performance. Central banks with explicit inflation targets communicate much more than their target to the public. There are infinitely many ways that the Riksbank could try to achieve its 2 percent target. Each way - or "policy rule" - affects private-sector expectations differently. Each rule and its associated expectations has unique impacts on the public's economic decisions. To reduce the likelihood of mistaken public expectations, the Riksbank communicates the particular rule that it tries to follow.

Communicating the rule is challenging. To achieve its inflation target, the Riksbank analyzes a vast array of data — domestic and foreign inflation and real economic developments and forecasts, current and prospective values of the krona, public and financial market expectations of inflation, and even political events at home and abroad. ${ }^{2}$ By describing how these facts and conjectures influence its choice of the path for the repo rate, the Riksbank is explaining its policy rule: how the central bank reacts to various kinds of news that affect Swedish inflation and real activity. Of course, the Riksbank, and no central bank,

\footnotetext{
${ }^{1}$ Total assets more than tripled between the third quarter of 2008 and the first quarter of 2009 and remained elevated until the second half of 2010. Assets have nearly doubled over the negative policy rate period beginning in 2015.

${ }^{2}$ See Sveriges Riksbank (2018, chapter 1) for examples.
} 
follows a simple algebraic rule that can be precisely and succinctly communicated. But it does respond systematically to economic conditions and that systematic behavior guides the public's formation of expectations about future monetary policy actions.

The Swedish government's net-lending target, while commendable from the viewpoint of fiscal sustainability, does nothing to communicate the fiscal behavior that tries to achieve the target. This is a potentially serious shortcoming of Sweden's fiscal framework, a shortcoming shared by governments the world over. Governments can perhaps be forgiven for confounding rules and targets. Even the International Monetary Fund uses the term "rule" to describe fiscal targets and restraints, rather than to characterize how the fiscal authority behaves [Schaechter et al. (2012)].

Because this paper focuses on how interactions among fiscal, monetary, and public behavior determine the economy-wide price level, to avoid confusion I will delineate between targets and rules. Targets refer to inflation at 2 percent and net lending at 1 percent, while rules describe the policy behavior that achieves those targets. A rule characterizes how the choice of a policy instrument - the repo rate, tax rates, expenditure components - depends on prevailing economic conditions. I argue that the policy rules are all-important for determining the price level and, by extension, the performance of the macro economy.

\subsection{Sketch of PAPER}

Before getting into details about Sweden, it is necessary to lay some groundwork for understanding how and why it is essential to study monetary and fiscal policies together, rather than separately. To that end, I describe the nature of policy interactions in any wellfunctioning equilibrium. Fundamental economic principles carry some critical implications that conflict with beliefs (i)-(iii). First, it is the joint monetary-fiscal policy regime that determines an economy's inflation rate. Second, monetary policy actions always have fiscal consequences - consequences that may be large at times - and how fiscal policy reacts to those consequences matters for the ultimate impacts of the monetary policy actions. Finally, the rule that the government pursues implements to pursue debt stabilization matters for the central bank's ability to achieve its mandates.

With that economic background in place, the paper turns to analyze features of Swedish macroeconomic policies and recent Swedish economic developments. These include

1. negative bond yields over the maturity structure, which constitute prima facie evidence of a fiscal policy that reduces social welfare, but also reflect the low-interest rate environment in which the Swedish economy finds itself;

2. the fragility - in the sense of potentially inducing instability in government debt - of 
Sweden's net-lending target, for reasons first articulated by Phillips (1954);

3. evidence of Swedish fiscal policy behavior and the backing that it provides for monetary policy;

4. an explanation of how, particularly in low-inflation periods, monetary policy actions can generate potentially substantial fiscal impacts in subtle ways that are not part of typical economic analyses at central banks and ministries of finance.

The paper's aim is not to criticize Swedish policies. Sweden's fiscal situation is sound: the government owns equities and its net financial position is positive. But the Swedish government nonetheless issues krona-denominated debt, so the analysis in this paper applies to Sweden, as it would to less fiscally sound economies. The paper tries to shed light on how monetary and fiscal policies in Sweden jointly determine macroeconomic outcomes. Along the way, the paper may point toward alternative fiscal rules that are consistent with the aims of Sweden's Fiscal Policy Framework and are more compatible with the job that the Riksbank has been tasked to perform.

\section{Monetary and Fiscal Policy Basics}

Much discourse about macroeconomic policies applies the following logic. The central bank sets its policy instruments - a short-term nominal interest rate, the level of bank reserves, the size and composition of its balance sheet - but does not set taxes and government expenditures. The government chooses the level and composition of various taxes and expenditures and the quantity and maturity structure of the debt it issues, but not the variables the central bank controls. Having established who controls what, analyses of policy impacts often proceed along similar lines to ask: How do changes in the central bank's (government's) instruments affect the economy, holding fixed fiscal (monetary) instruments? Although such questions seem to make sense on the surface, basic economic reasoning tells us that it is rarely possible to change a monetary (fiscal) instrument without eventually changing fiscal (monetary) instruments in particular ways.

Research over the past 25 years establishes this reasoning to emphasize that monetary and fiscal policy jointly determine the economy-wide level of prices and the rate of inflation. ${ }^{3}$ Out of that literature has emerged the understanding that two distinct combinations of monetary

\footnotetext{
${ }^{3}$ Early contributors include Leeper (1991), Sims (1994), Woodford (1995), and Cochrane (1999). Leeper and Walker (2013) and Leeper and Leith (2017) are recent overviews. Leeper (2016) explains why central banks - even when they are politically and operationally independent-need to pay attention to fiscal behavior.
} 
and fiscal policy behavior - policy regimes - can determine the price level and stabilize the level of government debt.

\subsection{Policy Regimes}

Table 1 summarizes the policy mixes that determine inflation and stabilize debt. To make the arguments clear, I make stark and unrealistic assumptions about policy behavior. The arguments go through with more plausible assumptions.

The first regime reflects the conventional view that monetary policy actively adjusts the policy interest rate to lean against inflation, while fiscal policy passively adjusts primary budget surpluses - revenues less expenditures, not including interest payments on government debt - to stabilize the long-run debt-GDP ratio. Taylor's famous rule falls into this regime: the central bank raises the policy interest rate more than one-for-one with the inflation rate and raises the interest rate more modestly when the output gap increases [Taylor (1993)]. ${ }^{4}$ Because monetary policy focuses on stabilizing inflation and the real economy, fiscal policy must ensure that government debt remains well behaved. When fiscal policy makes taxes rise with the level of real government debt - nominal debt deflated by the price level — by more than enough to cover interest payments and some of the principal, the debt-GDP ratio will be stable in the long run. Many economists believe this regime prevails during "normal" economic times. All inflation-targeting central banks believe they operate in this regime.

\begin{tabular}{|c|c|c|}
\hline $\begin{array}{r}\text { Policy } \\
\text { Authority }\end{array}$ & \multicolumn{2}{|c|}{$\begin{array}{l}\text { Monetary-Fiscal Policy Regimes that } \\
\text { Determine Inflation and Stabilize Debt }\end{array}$} \\
\hline & Conventional & Alternative \\
\hline & View & View \\
\hline Monetary & Aggressively raises interest & Weakly raises interest \\
\hline Rule & rate with inflation & rate with inflation \\
\hline Fiscal & Raises primary surplus & Pursues other objectives \\
\hline Rule & with real debt & besides debt stabilization \\
\hline Label & "Active Monetary & "Passive Monetary \\
\hline & Passive Fiscal Policies" & Active Fiscal Policies" \\
\hline
\end{tabular}

Table 1: Monetary-Fiscal Policy Mixes

A second, alternative, regime can also determine inflation and stabilize debt. In this regime, fiscal policy pursues other objectives, such as countercyclical policies or redistribution

\footnotetext{
${ }^{4}$ For reasons first articulated by Obstfeld and Rogoff (1983), monetary policy cannot deliver a unique inflation rate in a pure fiat currency regime. Cochrane (2011) and Sims (2013) recently emphasized that the Taylor rule permits explosive inflation paths to be equilibria, along with the stable inflation outcome that economists usually focus on.
} 
of income, by setting primary surpluses - defined as tax revenues less expenditures, excluding interest payments on outstanding debt - independently of debt and the price level. Monetary policy chooses the interest rate so that it responds only weakly — or not at all — to inflation, which permits expansions in government debt to raise the price level. Higher price levels and lower bond prices reduce the real market value of debt - the quantity of goods and services that a government bond can purchases - to make the debt-GDP ratio stable.

At a general level, there is nothing "good" or "bad" about the two policy regimes. Recent research on jointly optimal monetary and fiscal policies finds that the best mix of policies in terms of social welfare has elements of both the conventional and the alternative views [Sims (2013) and Leeper and Zhou (2013)]. Both regimes deliver the broad macroeconomic policy goals of determining inflation and stabilizing government debt. But because monetary and fiscal actions have different impacts in the two regimes, it is essential for policymakers to know in which regime the economy resides.

Because U.S. monetary policy behavior was been widely studied, I will point out several instances since America left the gold standard in April 1933 in which the Federal Reserve seems to have followed this alternative behavior: from April 1933 until about 1936; throughout World War II until the Treasury-Fed Accord in March 1951; much of the 1970s; the 2008 financial crisis and its aftermath. ${ }^{5}$ And there have been times when fiscal policy pays scant attention to debt in order to pursue other objectives: despite extremely high war debt, in 1948 Congress overrode President Truman's veto and cut taxes; the Economic Recovery Plan of 1981 increased primary deficits even as the debt-GDP ratio was rising from its post-war low in the early 1980s; both the Economic Growth and Tax Relief Reconciliation Act of 2001 and the Jobs and Growth Tax Relief Reconciliation Act of 2003 cut taxes at times of rising debt; the American Recovery and Reinvestment Act of 2009 increased spending and cut some taxes despite rising debt; even with record peacetime government debt levels, in December 2017 the U.S. government passed a major cut in taxes. ${ }^{6}$

During and since the financial crisis of 2007, central banks around the world have maintained policy interest rates that are pegged at extraordinarily low levels with the aim of stimulating real economic activity. This behavior places monetary policy into the "alternative view" category. At the same time, fiscal policies - particularly in Europe-have been adjusting to stabilize government debt following brief excursions into stimulative stances designed to help lift economies out of recession. By table 1's categorizations, the mix of pegged interest rates and stabilizing fiscal policy, if people expect it would last forever, do not deliver an equilibrium in which inflation is determined. ${ }^{7}$

\footnotetext{
${ }^{5}$ See Taylor (1999), Clarida et al. (2000), Lubik and Schorfheide (2004), and Davig and Leeper (2006).

${ }^{6}$ See Davig and Leeper (2006), Bhattarai et al. (2016), and Bianchi and Ilut (2017).

${ }^{7}$ This is called "price-level indeterminacy," and is a topic that has received a great deal of attention in the
} 


\subsection{Fiscal Consequences of Monetary Policy}

To keep this discussion focused, in what follows I consider only the conventional mix of monetary and fiscal policy behavior. That policy combination underlies the Riksbank's perceptions of its behavior and the rationale for Sweden's Fiscal Policy Framework. The independent Riksbank pursues its inflation target, while the government acts to ensure debt is stable. This conventional view of macroeconomic policies is the foundation of monetary and fiscal institutions in nearly all countries.

My key message is: under this conventional policy mix, monetary and fiscal policies must interact in certain well-specified ways. It is not possible for monetary and fiscal policy to operate independently of each other and still deliver good economic performance. Understanding the nature of these interactions is essential to formulating effective policy rules.

Monetary policy actions always have fiscal consequences. ${ }^{8}$ Let's start with something routine: the Riksbank lowers the repo rate in order to raise inflation. This isn't the end of the story: a lower repo rate tends to lower all interest rates, including those on government debt, so interest payments on outstanding debt decline.

Now fiscal policy comes into play. Those lower interest payments reduce fiscal needs. To ensure that government debt is stable, taxes must be lower or expenditures must be higher in the future to offset the reduced debt service. Without these fiscal adjustments, government debt would steadily fall, eventually making the government a net lender to the private sector.

But there is actually more to the fiscal response than simply stabilizing debt. Lower interest payments on government bonds reduce the wealth of holders of those bonds. If those lower interest receipts do not trigger an expectation of eventually lower taxes to compensate for the reduced wealth, lower wealth will lead to reduced demand for goods and serviceslower aggregate demand - and a lower price level.

Because the Riksbank initially reduced the repo rate in the hope of raising aggregate demand and inflation, the negative wealth effect can thwart the Riksbank's efforts. To support monetary policy, fiscal policy needs to provide the fiscal backing that adjusts future taxes in the opposite direction to price-level movements. A higher price level — the Riksbank's immediate goal - requires a fiscal rule that lowers future taxes, while a lower price level calls for a policy that raises taxes. Such a rule eliminates the wealth effects of central bank changes in interest rates to deliver the desired effect of monetary policy on aggregate demand.

The fiscal rule under the conventional view in table 1 both stabilizes debt and provides

academic literature. Indeterminacy means that the inflation rate is not pinned down by policy and is subject to potentially volatile fluctuations that arise from self-fulfilling expectations of inflation by the private sector. Woodford (2003) explains that determinacy is a minimal requirement for optimal policy.

${ }^{8}$ Tobin (1980) and Wallace (1981) make this point. 
the necessary fiscal backing for monetary policy. A rule that raises future surpluses whenever real debt increases has two components to it. First, for a fixed price level, higher nominal debt brings forth higher surpluses to ensure government debt is stable. Second, for a fixed level of nominal debt, a lower price level creates the expectation of higher future taxes to provide the fiscal backing for monetary policy's inflation-targeting actions. The passive policy rule in the table happens to deliver both desirable outcomes.

The message is: to successfully raise inflation, the Riksbank's looser monetary policy (lower repo rate) necessarily requires looser fiscal policy (smaller budget surpluses) at some point. That fiscal response is essential for the Riksbank to be able to control inflation and fulfill the price-stability policy mission that the Rigsdag set out for the bank in the Sveriges Riksbank Act.

Unfortunately, not all fiscal rules both stabilize debt and back monetary policy. This is why it's important for governments to move beyond adopting targets, toward describing the behavior that achieves the targets. Both outcomes rely on fiscal expectations. If markets know that higher real debt eventually leads to higher stabilizing surpluses, then fiscal policy will not run into sustainability problems, as investors are assured the government will fulfill its financial commitments. This argument figures prominently in the Swedish fiscal policy framework [Swedish Government (2011), pages 5, 7, and 12, for example]. If bondholders know that lower taxes are sure to follow lower interest receipts, then monetary policy's adverse wealth effects will not arise, and interest-rate policy will affect inflation as intended. This point is missing from the Swedish fiscal framework.

Appropriate fiscal backing for monetary policy is critical for the Riksbank to achieve price stability. In a country like Sweden, with an explicit fiscal target, it is essential to ensure that the fiscal rules used to implement the target provide appropriate backing for monetary policy. A correctly designed rule anchors people's expectations on the belief that fiscal policy will, in time, react appropriately to monetary policy by eliminating the wealth effects that monetary policy produces.

\section{INTERNATIONAL EXAMPLES}

To gain a deeper understanding of the monetary-fiscal combinations in table 1, it is helpful to consider actual instances when policy behavior departed from the conventional monetaryfiscal regime. 


\subsection{An Important American Case}

Recovery from the Great Depression illustrates that the alternative monetary-fiscal policy mix has been an explicit policy choice. ${ }^{9}$ President Franklin D. Roosevelt took office in March 1933 at the lowest point of the Great Depression. Compared to the third quarter of 1929, real GNP was 36 percent lower, industrial production had been cut in half, unemployment rose from almost nothing to a quarter of the workforce, and the price level had fallen 27 percent. The new president committed to raise the price level by achieving "...the kind of a dollar which a generation hence will have the same purchasing power and debt-paying power as the dollar we hope to attain in the near future" [Roosevelt (1933b)]. The first step toward permanently raising the price level was to abandon the gold standard in favor of what Roosevelt called a "managed currency" [Roosevelt (1933a)].

Abandoning convertibility of the dollar to gold included abrogating the gold clause, a contractual provision that gave creditors the option to receive payment in gold, on all future and past public and private contracts. This changed the nature of government debt. Under convertibility, even though government bonds paid in dollars, the Treasury was required to convert those dollars into gold on demand. When the Treasury didn't have the gold on hand, it had to acquire the gold, typically through higher taxes. The new "managed currency" standard broke the automatic link between new bonds and future surpluses: government bonds were simply promises to pay dollars, which the U.S. government could freely create without adjusting taxes. ${ }^{10}$

Roosevelt used three strategies to convince the public that higher government debt would not necessitate higher future taxes. First, he made policy depend on the state of the economy, saying he would run bond-financed deficits until the economy recovered. Second, he emphasized the temporary nature of the policy by distinguishing between the "regular budget," which he balanced, and the "emergency budget," whose deficits were driven by spending designed to provide relief to those the depression had harmed. Finally, Roosevelt raised the political stakes by pitching economic recovery as a "war for the survival of democracy" [Roosevelt (1936)]. The strategies appeared to work because expected inflation began to rise by spring 1933 [Jalil and Rua (2017)].

Monetary policy behaved passively through the recovery. After the United States left gold, the Fed no longer needed to keep interest rates high to staunch the outflow of gold and the New York Fed reduced its discount rate to 1.5 percent in February 1934, where it remained until August 1937, when it was lowered to 1 percent. From November 1933 to

\footnotetext{
${ }^{9}$ This draws on Jacobson et al. (2017).

${ }^{10}$ Today all but the 10 percent of Treasury debt that is indexed to inflation is also merely a promise to pay future dollars.
} 
February 1937, the Fed conducted no open-market purchases of Treasury securities. One contemporary observer wrote that the Federal Reserve "served merely as a technical instrument for effecting the Treasury's policies" [Johnson (1939, p. 211)]. Clearly, the Fed did not follow anything resembling a Taylor rule; instead, monetary policy permitted the expansion in government debt to stimulate the economy, as it does in the alternative policy mix.

Economic recovery was rapid. Real GNP returned to its pre-depression level in 1937. Price levels - consumer and wholesale price indexes and the GNP deflator-rose. The deflator regained its 1920s levels, while the other two fell somewhat short.

Historians like Friedman and Schwartz (1963) and Romer (1992) attribute recovery to higher growth in the supply of money. After America left the gold standard, the Treasury bought the gold that flowed into the country from a politically unstable Europe and paid for that gold by directly expanding bank reserves and high-powered money. But that explanation overlooks the significant expansion in government debt that took place. The dollar value of federal debt outstanding doubled in the six years after leaving the gold standard, reflecting the substantial fiscal stimulus associated with Roosevelt's relief programs.

Remarkably, this expansion in nominal debt did not raise the debt-GNP ratio. Figure 1 plots the par and market values of gross federal debt as percentages of GNP from 1920 to 1940. The vertical line marks departure from gold in April 1933. After bottoming out in September 1929 at 15.6 percent, the debt-GNP ratio rose steadily while the United States was still on gold, reaching 44.7 percent in March 1933. It then remained below 45 percent through the end of 1937. Economic recovery raised both the price level and the real level of economic activity, ensuring that the debt-GNP ratio was stable.

In this alternative policy mix, the Federal Reserve behaved passively, permitting the fiscal expansion to raise aggregate demand and with it, prices and output. With this policy mix, there need not be any conflict between fiscal expansion and fiscal sustainability because, as the data in figure 1 neatly illustrate, the fiscal expansion did not increase debt relative to the size of the economy.

\subsection{Recent International Cases}

Countries have not always provided appropriate fiscal backing. ${ }^{11}$ In recent years, Brazil followed a fiscal policy that was unresponsive to debt, while its central bank sought to target inflation. The 1988 constitution indexed government benefits to inflation, which placed 90 percent of expenditures out of legislative control. At the same time, tax increases were politically infeasible, leading to growing primary deficits with no prospect of reversal. When inflation began to rise, the central bank aggressively raised interest rates, just as the

\footnotetext{
${ }^{11}$ Leeper (2017) discusses these and other examples in detail.
} 


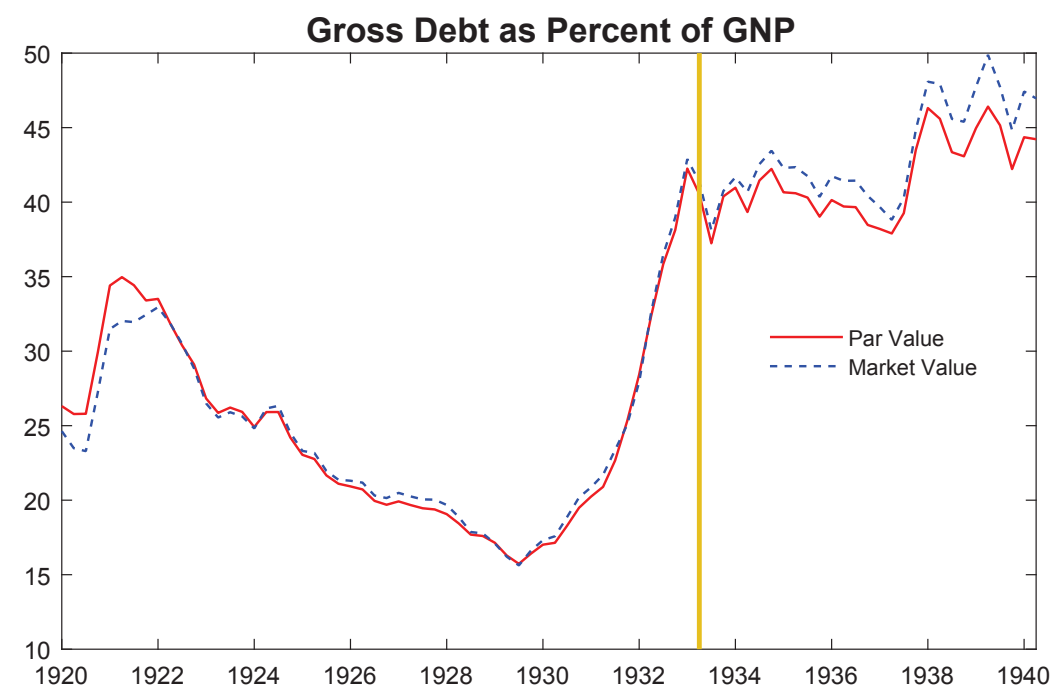

Figure 1: Par and market value of gross federal debt as a percentage of GNP. Source: Hall and Sargent (2015), Balke and Gordon (1986), and authors' calculations. Vertical line marks departure from the gold standard.

Taylor principle instructs. Debt service rose, driving up aggregate demand and inflation. In December 2015, the primary deficit was 1.88 percent of GDP, but the gross deficitprimary plus interest payments - was 10.34 percent of output. Figure 2 plots Banco Central do Brasil's policy rate, the Selic, along with the consumer price inflation rate from 2013 through 2015. Despite a doubling of the policy rate, the inflation rate rose by nearly 5 percentage points: monetary policy does not appear to be controlling inflation. In fact, inflation began to retreat in 2016 only after the central bank had stabilized the Selic at 14.25 percent for a year.

It is tempting to infer that Brazil's problems stemmed from dysfunctional fiscal policy. Surely, if fiscal policy follows well-specified guidelines that ensure "responsible" fiscal behavior, monetary policy will be able to control inflation. In fact, the explanation lies in an incompatible combination of monetary and fiscal policies that were both active, in table 1's nomenclature.

Switzerland has had "responsible" fiscal targets for 15 years and it takes those targets seriously. By "seriously" I mean the government actually achieves those targets. ${ }^{12}$ Since a nationwide referendum in 2001, Switzerland has pursued a debt brake, which limits spending to average revenue growth over several years. If spending differs from this limit, the difference is debited or credited to an adjustment account that has to be corrected in coming years. Debt brakes have a built-in error-correction mechanism intended to restrict the size

\footnotetext{
${ }^{12}$ This draws on Leeper (2016) and Bai and Leeper (2017).
} 


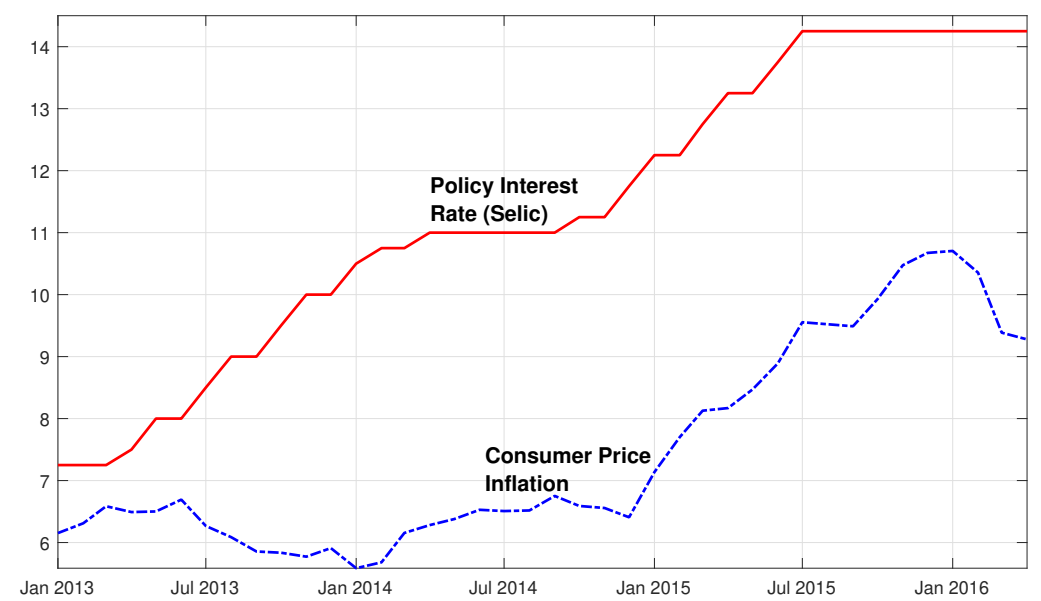

Figure 2: Brazilian monetary policy interest rate and consumer price inflation rate. Source: IHS Global Insight.

of government debt. ${ }^{13}$
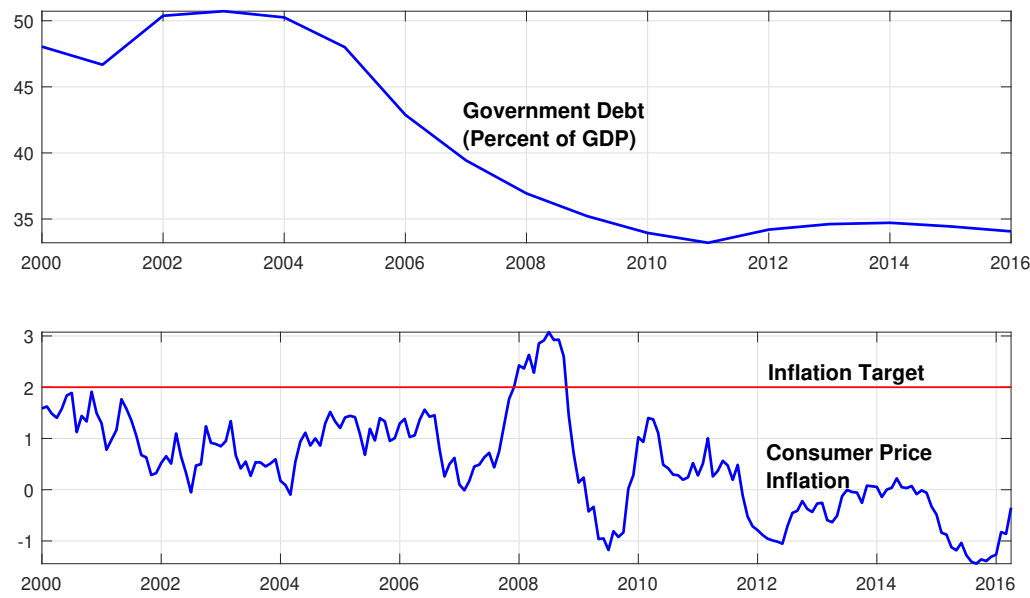

Figure 3: Debt-GDP ratio and CPI inflation rate in Switzerland. Source: Swiss National Bank.

The top panel of figure 3 suggests that Swiss fiscal targets have worked to limit debt growth. Government debt has steadily fallen over the past 15 years and now is about 35 percent of GDP. Remarkably - and Switzerland, along with Sweden, may be the sole exceptions - debt either continued to fall or was flat during the financial crisis. This stunning outcome is a testament to the effectiveness of fiscal targets that are reached.

\footnotetext{
${ }^{13}$ See Danninger (2002) and Bodmer (2006) for additional details and analyses.
} 
But this prudent fiscal policy may have come at a cost in terms of inflation targeting. Switzerland has a 2 percent inflation target that has been missed chronically. In Switzerland, inflation has been persistently below target since the beginning of 2009. Low inflation rates do not seem to be the result of inadequate efforts by monetary policy: policy interest rates have been negative since the beginning of 2015 .

The Swiss case illustrates that fiscal backing for monetary policy must be symmetric. When monetary policy reduces (raises) interest rates and interest payments on government debt, fiscal policy needs to reduce (raise) taxes. Fiscal rules designed primarily to reduce government debt may interfere with the symmetry of fiscal backing.

These international examples offer evidence of how monetary and fiscal policies that are inconsistent with each other can produce undesirable economic outcomes. Of course, many other factors also affect Brazilian and Swiss data, so this evidence is merely suggestive. Each is a case in which monetary and fiscal authorities independently pursue their objectives and fiscal authorities fail to provide the fiscal backing needed for the central banks to control inflation.

\section{Negative Nominal Bond Yields}

Like several other European countries, Sweden has been going through the unusual situation in which nominal government bond yields have been negative, even at horizons as long as five years. While there are many reasons that nominal yields have turned negative-economic weakness in the wake of the global financial crisis, aging populations, and so forth - monetary policy behavior is certainly a major factor. Lower monetary policy interest rates tend to reduce interest rates across the maturity spectrum.

Persistently negative government bond yields may be prima facie evidence that fiscal policy could be improved. Essentially, the private sector is telling the government that it is willing to pay for the right to lend to the government. When yields remain negative, it must mean that the government is not taking the private sector up on its generous offer.

Medium-term government bond yields are negative because demand for those safe assets is very strong. Strong demand bids up bond prices at the relevant maturities, driving down yields. If the government were to respond to the strong demand by increasing supply of the desirable assets, yields would rise. Negative yields, therefore, may reflect a "shortage" of high-demand assets.

Although the logic of why negative bond yields suggest suboptimal fiscal behavior may be obvious, a simple numerical example may clarify the issues. ${ }^{14}$ Suppose that in 2017 , the

\footnotetext{
${ }^{14}$ This example comes from a conversation with Jon Faust.
} 
market price of a government bond that pays SEK 100 in 2018 is SEK 105, implying a -5 percent annual yield. For the sake of this example, imagine that the bond is bought by the Riksbank by crediting the government's account at the Riksbank by SEK 105, the amount by which assets and liabilities of both the government and the Riksbank increase. When the bond comes due in 2018, the government pays the Riksbank SEK 100, so its assets with the central bank decline by SEK 100, while its liabilities decline by SEK 105. The mirror of this transaction has the Riksbank's assets decline by SEK 105 and its liabilities by SEK 100.

The following year, the government transfers SEK 5 to the private sector, paid for by crediting banks' deposits at the Riksbank by SEK 5. Government balances with the Riksbank fall by SEK 5; liabilities of the Riksbank decline by those 5 krona and rise by the equivalent amount from the increase in bank reserves. Banks' deposits with the Riksbank earn the repo rate, which in fall of 2017 was -0.5 percent. If we denote the repo rate by $r^{D}$, then each year the Riksbank's liabilities decline by $1+r^{D}<1$ because $r^{D}<0$. After $K$ years, the Riksbank's liabilities in the form of bank reserves have declined by $-5\left(1+r^{D}\right)^{K}$. Over time, this number gets smaller, so that the initial expansion in reserves is self-extinguishing and the total expansion in bank reserves is $5 /\left(1+r^{D}\right)=5.025$ krona.

This example illustrates one channel by which the private sector can be made better off when government bond yields are negative and the government issues additional government bonds to take advantage of those negative rates. More generally, the government could do practically anything productive with the proceeds from negative bond yields - invest in a sovereign wealth fund, finance infrastructure projects with positive returns, or drop newly printed cash onto Gamla Stan. A government that does not pursue these policies is reducing its citizens' welfare.

Figure 4 plots estimated government bond yields at maturities of one, three, five, and 10 years, along with the path of the repo rate set by the Riksbank. Immediately before and fairly continuously since the Riksbank adopted a negative repo rate in February 2015, bond yields out to five years also turned negative. In August 2016, even the 10-year yield briefly flirted with zero. Table 2 reports the average yields over the 33 months since the negative interest rate policy was adopted. All maturities out to five years have averaged negative yields for over two and a half years, plenty of time for the government to adopt welfare-improving policies that capitalize on bondholders' willingness to pay for the privilege of lending to the government.

I do not know why governments refuse to issue more bonds when their nominal yields are negative. But the current fiscal climate in many countries seems to maintain that any expansion in government debt is "bad," while any contraction in debt is "good." This is a climate that locks up fiscal policy and throws away the key. 


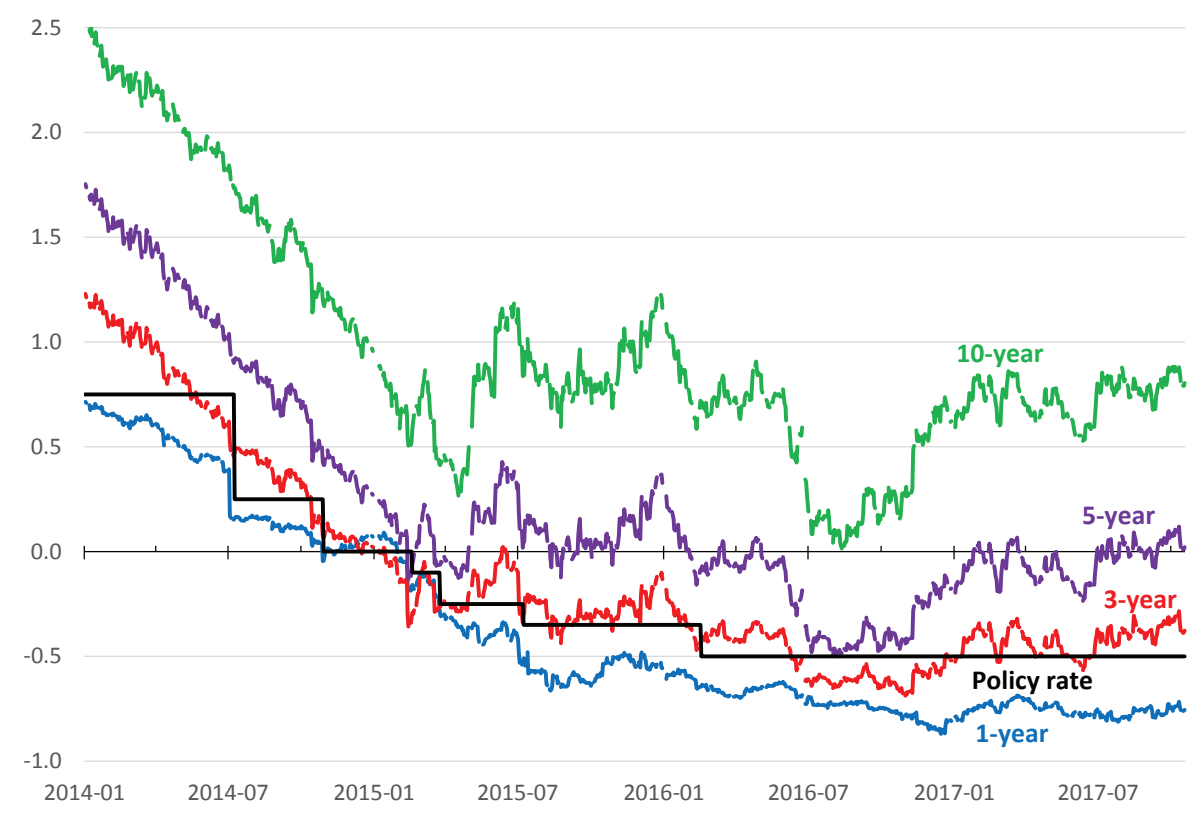

Figure 4: Estimated zero-coupon government bond yields as various maturities, daily data. Source: Sveriges Riksbank.

\begin{tabular}{rr}
\hline 3-month & -0.61 \\
6-month & -0.64 \\
1-year & -0.64 \\
2-year & -0.54 \\
3-year & -0.39 \\
4-year & -0.23 \\
5-year & -0.06 \\
10-year & 0.67 \\
Repo & -0.42 \\
\hline
\end{tabular}

Table 2: Average of estimated zero-coupon yields between 18 February 2015 and 18 October 2017, daily data. Source: Sveriges Riksbank

\section{How a Net-Lending Target Works And Why It's Fragile}

Swedish fiscal policy pursues a net-lending target that is currently one percent of GDP over the medium term. To understand that policy's implications for government debt developments, we need to study how government debt evolves over time. Government debt's evolution is governed by the government's budget identity, which may be written as

$$
Q_{t} B_{t}=\left(1+\rho Q_{t}\right) B_{t-1}-S_{t}
$$


where $B_{t}$ is the nominal value of the government's bond portfolio, $Q_{t}$ is the nominal price of the portfolio, and $S_{t}$ is the nominal primary budget surplus. The primary surplus is the difference between total tax revenues and total government expenditures, excluding interest payments on outstanding debt. As written, the budget identity assumes that all government bonds are in nominal krona. In fact, Sweden also issues inflation-linked bonds and foreign currency bonds, but in 2017 over half of Swedish government debt was krona denominated.

We specialize the specification of government debt by assuming that all debt pays zero coupons and that the maturity structure decays at the constant rate $\rho$ each period. If $B_{t-1}(t+j)$ is the quantity of zero-coupon bonds outstanding in period $t-1$, which come due in period $t+j$, then $B_{t-1}(t+j)=\rho^{j} B_{t-1}$, where $B_{t-1}$ is the portfolio of such specialized bonds in period $t-1 .{ }^{15}$ Recent Swedish National Debt Office guidelines aim for an average maturity of nominal krona debt of between 4.3 and 5.5 years [Riksgälden Swedish National Debt Office (2017)].

Define the gross nominal rate of return on the bond portfolio as

$$
1+R_{t}=\frac{1+\rho Q_{t}}{Q_{t-1}}
$$

This permits expressing the budget identity in terms of the evolution of the market value of debt, denoted by $Q_{t} B_{t}$, as

$$
Q_{t} B_{t}=\left(1+R_{t}\right) Q_{t-1} B_{t-1}-S_{t}
$$

Let $N_{t}$ denote net lending by the government, defined as

$$
N_{t} \equiv-\left(Q_{t} B_{t}-Q_{t-1} B_{t-1}\right)
$$

Net borrowing is the change in the market value of outstanding government debt, so net lending is the negative of this change.

Then we can write the budget identity as

$$
N_{t}=-\left(Q_{t} B_{t}-Q_{t-1} B_{t-1}\right)=S_{t}-R_{t} Q_{t-1} B_{t-1}
$$

where the term $R_{t} Q_{t-1} B_{t-1}$ reflects interest payments on outstanding debt, which is also called debt service costs.

To relate the budget identity to the government's net-lending rule, we scale all variables

\footnotetext{
${ }^{15}$ This specialization permits us to extract the implications of the existence of a maturity structure for government debt in a straightforward and intuitive manner.
} 
by nominal GDP, $Y_{t}$, and express ratios to aggregate income as lower-case letters. Letting $b_{t}$ denote the ratio of the market value of debt to GDP, expression (1) becomes ${ }^{16}$

$$
n_{t}=-\left(b_{t}-\frac{1}{1+G_{t}} b_{t-1}\right)=s_{t}-\frac{R_{t}}{1+G_{t}} b_{t-1}
$$

Denote the net-lending target by $n^{*}$. When Sweden sets this target at 1 percent of GDP, $n^{*}=.01$. Government policy aims to achieve this target by adjusting its fiscal instrumentstaxes, government consumption and investment, and transfer payments - which are summarized by the primary surplus, $s_{t}$. We shall treat the primary surplus as the government's fiscal instrument.

\subsection{AlWAYS ON TARGET}

Initially, let's make the simplifying and extreme assumption that the government hits this target every period, so that $n_{t}=n^{*}$ all the time. Imposing this on the government's budget identity in expression (2) implies that

$$
s_{t}=n^{*}+\frac{R_{t}}{1+G_{t}} b_{t-1}
$$

This expression is a rule for setting the surplus that makes net lending always equal to its target. To hit the net-lending target every period, the primary surplus must equal that target value plus the real interest payments on debt carried over from the past. In this expression, $R_{t} /\left(1+G_{t}\right)$ is the real-inflation-adjusted-rate of return on the government's bond portfolio.

The extreme assumption produces extreme policy behavior: the government must adjust the real primary surplus one-for-one with real debt service. This has two consequences. First, to achieve the net-lending target every period, the government loses the flexibility to pursue other fiscal goals - macroeconomic stabilization, income distribution, and so forth-even in the short run. Forcing net lending to be always on target makes primary surpluses the exact function of select economic conditions that expression (3) describes.

Second, the government must react to any economic disturbance that raises debt service by raising the primary surplus. If the Riksbank reduces the repo rate in order to stimulate inflation, for example, then at least initially real interest rates are likely to fall at all maturities. This reduces the real return on outstanding debt and, hence, debt service costs.

\footnotetext{
${ }^{16}$ In (2) the variables are defined as $b_{t} \equiv \frac{Q_{t} B_{t}}{Y_{t}}, s_{t} \equiv \frac{S_{t}}{Y_{t}}, r_{t} \equiv \frac{R_{t}}{\left(1+g_{t}\right)\left(1+\pi_{t}\right)}, n_{t} \equiv \frac{N_{t}}{Y_{t}}$, and $1+G_{t} \equiv \frac{Y_{t}}{Y_{t-1}}=$ $\frac{P_{t}}{P_{t-1}} \frac{y_{t}}{y_{t-1}}=\left(1+\pi_{t}\right)\left(1+g_{t}\right)$, where $G_{t}$ is the net growth rate of nominal GDP, $Y_{t}$, and $P_{t}$ is the general price level, so $\pi_{t}$ is the net inflation rate, and $g_{t}$ is the net growth rate of real GDP.
} 
The government then must reduce primary surpluses - that is, engage in expansionary fiscal policy - to maintain the net-lending target.

Many other economic shocks will also affect debt service because interest rates on government debt are highly sensitive to both domestic and foreign disturbances. Any shock that reduces debt service, must be met with lower primary surpluses if net lending is to stay on target.

Notice that debt service in (3) can be rewritten as

$$
\frac{R_{t}}{1+g_{t}} \frac{B_{t-1}}{P_{t}}
$$

where $1+g_{t}$ is real economic growth. Now passive fiscal behavior is apparent: a higher price level calls for a lower surplus. In principle, there is no conflict between a net-lending target and passive fiscal backing for monetary policy. The fiscal behavior that (3) describes delivers both the lending target and the fiscal backing.

\subsection{Gradually on Target}

Neither the Swedish government, nor any government, aims to keep net lending on target all the time. Instead, the target is intended to be hit on average over the course of economic cycles. We can generalize this analysis by allowing the adjustment to the net-lending target to be gradual. One fiscal rule that gradually achieves the net-lending target is

$$
s_{t}-\bar{s}=-\gamma\left(n_{t}-n^{*}\right), \quad \gamma>0
$$

where $\bar{s}$ is the long-run primary surplus-GDP level. By this rule, whenever net lending is above target, $n_{t}>n^{*}$, the government makes the primary surplus lower than its long-run value. A lower surplus reduces net lending (or increases government borrowing) to reduce net lending back to target over time. The rule in (4) is a stylized description of fiscal behavior. Economic theory often posits stylized behavior in order to focus attention on a single aspect of what policy does - in this case, how surpluses react to net lending. A rule like (4) could be far more complicated to try to capture actual policy behavior, but that would merely make the analysis more complex and less transparent.

For this net-lending rule to stabilize government debt and reach the net-lending target in the long run, primary surpluses must respond to net lending with sufficient strength. This implies a restriction on the coefficient $\gamma$ in (4). To derive that restriction, substitute the fiscal

rule, (4), into the government's budget identity, (2), to obtain an equation that describes 
how the real market value of outstanding debt-GDP evolves over time

$$
b_{t}=\frac{1}{1+G_{t}}\left(1+\frac{R_{t}}{1+\gamma}\right) b_{t-1}-\frac{\bar{s}+\gamma n^{*}}{1+\gamma}
$$

Stability requires that over time the market value of debt as a share of output converges to a constant, which requires that the coefficient on lagged debt in (5) lies between 0 and $1^{17}$

$$
0<\frac{1}{1+G_{t}}\left(1+\frac{R_{t}}{1+\gamma}\right)<1
$$

After some manipulation, we see that this restriction implies an appropriate range for the policy parameter $\gamma$

$$
1+\gamma>\frac{R_{t}}{G_{t}}
$$

Because debt stabilization is by nature about the long run, we can consider this condition when inflation, economic growth, and interest rates are at their constant long-run values. This allows us to link the nominal return on bonds, $R$, to three things: the rate at which bondholders discount the future, $\beta$, the growth rate of the economy, $g$, and the central bank's inflation target, $\pi^{*}$. We obtain the relationships $1+R=\beta^{-1}(1+G)=\beta^{-1}(1+g)\left(1+\pi^{*}\right)$ and $1+r=\beta^{-1}(1+g)$, were $1+g$ is the gross growth rate of real GDP and $1+r$ is the gross real interest rate. Substituting these long-run relations in for $R / G$ yields the restriction that government must make primary surpluses react to net lending with a coefficient that satisfies

$$
\gamma>\frac{\left(1+\pi^{*}\right)(r-g)}{\left(1+\pi^{*}\right)(1+g)-1}=\frac{\left(1+\pi^{*}\right)(r-g)}{G}
$$

This expression has a straightforward interpretation. $\pi^{*}$ is the central bank's inflation target, so in the case of Sweden, $1+\pi^{*}=1.02$, given the Riksbank's 2 percent inflation target. $r-g$ is the difference between the real interest rate on government bonds and the growth rate of real GDP in the long run. Economies that permanently grow faster than the cost of borrowing have no need for fiscal rules because tax revenues are assured to grow more rapidly than real debt service; those fortunate economies can simply "grow out of deficits."

It is reasonable to assume that over the broad span of time in Sweden, the real interest rate exceeds the real growth rate. The denominator in (6) may be rewritten in terms of the growth rate of nominal GDP as $\left(1+\pi^{*}\right)(1+g)-1=G$, where $G$ is the net growth rate of nominal GDP, so it is a number like 0.04 when the price level and real output both grow at 2 percent annually. Higher nominal growth requires a smaller reaction of surpluses to net

\footnotetext{
${ }^{17}$ Technically, the coefficient on debt could also lie between 0 and -1 , but negative coefficients create oscillatory behavior that governments would usually want to avoid.
} 
lending for two reasons. First, higher real growth automatically reduces the debt-GDP ratio. Second, higher inflation reduces bond prices and, therefore, the market value of debt.

Table 3 reports threshold values for the responsiveness of surpluses to net lending in order to stabilize debt-GDP when long-run real interest and growth rates take on different combinations. Because the rule in (4) is written with a $-\gamma$, values in the table should be understood as making surplus deviations move in the opposite direction from net-lending deviations. These calculations impose that the Riksbank hits its $2 \%$ inflation target in the long run. When $\gamma$ exceeds these thresholds, in the long run the debt-GDP ratio is constant and equal to the discounted present value of the long-run primary surplus-GDP ratio.

\begin{tabular}{|cc|c|c|c|c|c|c|}
\hline growth rate (\%) & 0 & 1 & 2 & 3 & 4 & 5 \\
\hline real rate (\%) & & 0 & & & & & \\
1 & 0.51 & 0 & & & & \\
2 & 1.02 & 0.34 & 0 & & & \\
3 & 1.53 & 0.68 & 0.25 & 0 & & \\
4 & 2.04 & 1.01 & 0.51 & 0.20 & 0 & \\
5 & 2.55 & 1.35 & 0.76 & 0.40 & 0.17 & 0 \\
\hline
\end{tabular}

Table 3: Implications of combinations of long-run real interest rates and real growth rates for the minimum response of primary surpluses to net lending that will stabilize the debt-GDP ratio. Entries report threshold values that $\gamma$ in fiscal rule (4) must exceed. These calculations assume an inflation target of $2 \%$. Table excludes the negative threshold values when $g>r$.

\begin{tabular}{|cc|c|c|c|c|c|c|}
\hline & inflation rate (\%) & 0 & 1 & 2 & 3 & 4 & 5 \\
\hline real rate (\%) & & & & & & & \\
\hline 2 & 0 & 0 & 0 & 0 & 0 & 0 \\
3 & 0.50 & 0.33 & 0.25 & 0.20 & 0.17 & 0.15 \\
4 & 1.00 & 0.67 & 0.51 & 0.41 & 0.34 & 0.30 \\
5 & 1.50 & 1.00 & 0.76 & 0.61 & 0.51 & 0.44 \\
\hline
\end{tabular}

Table 4: Implications of combinations of long-run real interest rates and inflation rate targets for the minimum response of primary surpluses to net lending that will stabilize the debtGDP ratio. Entries report threshold values that $\gamma$ in fiscal rule (4) must exceed. These calculations assume a growth rate of real GDP of $2 \%$. Table excludes the negative threshold values when $g>r$.

Table 4 makes clear how the central bank's inflation target affects this threshold. A higher inflation target reduces the threshold, permitting the debt-GDP ratio to be stabilized with a weaker response of surpluses to net lending. It might seem odd that the inflation target would have an impact on long-run stabilization of the government debt. The reason 
for this is that a higher inflation target produces lower bond prices, which reduce the market value of debt as a share of GDP. A lower market value of debt, on average, makes it easier to stabilize the ratio.

The message is that even in the long run, monetary and fiscal policies must be consistent with each other.

\subsection{Alternative Representation of Fiscal Rule}

We can derive an alternative representation of the fiscal behavior that underlies the netlending target. This representation ties more closely to theoretical work on how monetary and fiscal policies interact. Combine (2) with the net-lending rule (4) to arrive at a rule that sets the primary surplus in response to net interest payments

$$
s_{t}=\frac{\gamma}{1+\gamma} \frac{R_{t}}{1+G_{t}} b_{t-1}+\frac{1}{1+\gamma}\left(\bar{s}+\gamma n^{*}\right)
$$

This expression generalizes the extreme policy behavior that appears in (3) when we assumed the government exactly hit the net-lending target, $n^{*}$, every period. Whereas in (3) the government increased the primary surplus one-for-one with interest payments, expression (7) instructs the government to gradually raise surpluses by the fraction $\gamma /(1+\gamma)$ of debt service to cover rising interest expenses. ${ }^{18}$

Section 6 reports some estimates of the surplus rules in equations (4) and (7).

\subsection{Net Lending vs. Change in DebT}

Given the definition of net lending, a policy that targets net lending is a very close cousin to a policy that targets the change in debt. Net lending is $n_{t}=-\left(b_{t}-\frac{1}{1+G_{t}} b_{t-1}\right)$, so when nominal GDP growth, $G_{t}$, is zero, this is simply the change in the market value of the debtGDP ratio. For this reason, it is useful to study the properties of a policy that targets the change in debt. Let $\Delta b_{t}$ denote the change in debt and $\Delta b^{*}$ its target value.

Now the government sets policy to raise the primary surplus whenever the change in debt exceeds target

$$
s_{t}-\bar{s}=\delta\left(\Delta b_{t}-\Delta b^{*}\right)
$$

so we restrict $\delta$ to be positive. Combining this rule with the government's budget identity

\footnotetext{
${ }^{18}$ The coefficient in $(7), \gamma /(1+\gamma)$, is less than one to make the adjustment gradual.
} 
produces an expression for debt's evolution over time ${ }^{19}$

$$
b_{t}=\left(\frac{\beta^{-1}+\delta}{1+\delta}\right) b_{t-1}-\frac{1}{1+\delta}\left(\bar{s}-\delta \Delta b^{*}\right)
$$

Debt will be stabilized by this policy only if the coefficient $\frac{\beta^{-1}+\delta}{1+\delta}<1$. But this can never happen because it requires that real interest rates are negative in the long run. ${ }^{20}$

The reason targeting the change in debt can never stabilize the debt-GDP ratio is obvious. If the change in debt target is positive and it is successfully achieved, then debt is growing at a constant rate as a share of the economy; if the target is negative and achieved, then debt is declining as a share of the economy. In either case, debt is not a stable fraction of GDP.

The only difference between a negative change in debt target and a net-lending target is that net lending scales past debt by the growth rate of nominal GDP. Of course, in periods when nominal GDP growth is small, positive net lending is essentially equivalent to a negative change in debt.

\subsection{What These Fiscal Rules Aim to Accomplish}

Countries adopt fiscal rules, not because the rules per se are virtuous, but because the rules help to achieve some broader objectives. Those broader objectives, according to the Swedish fiscal policy framework, are to use fiscal policy to raise the welfare of Swedish citizens through economic growth, redistribution of income, and stabilization of the macro economy. As the framework words it, "A fundamental precondition for being able to attain the overall objective of fiscal policy is the long-term sustainability of the public finances" [Swedish Government (2011, p. 5)]. One way to operationalize "long-term sustainability" is the achievement of a stable debt-GDP ratio over the long run.

Many years ago Phillips (1954) applied the theory of control to categorize three types of policy rules: proportional, integral, and derivative. He argued that the main driver of policy needs to be a proportional rule. The behavior that equation (4) describes makes deviations of the primary surplus from its long-run value proportional to deviations of net lending from target. One can add to that proportional behavior a response to cumulated deviations of debt from target - the "integral" component - if it is desirable to reduce how long it takes to return to target. Phillips points out that changes in the deviation of debt from target-

\footnotetext{
${ }^{19}$ As before, we examine how this rule operates over the long run in which interest rates and growth rates are constant.

${ }^{20}$ That is, making the coefficient on $b_{t-1}$ less than 1 requires that $1 / \beta<1$. But $\beta$, which determines how much people discount the future, is always between 0 and 1, implying that people are impatient and prefer to consumer sooner rather than later.
} 
"derivative" part - should be used only to dampen any oscillations that might otherwise be present.

Phillips' point is that a fiscal response to changes in debt- "derivatives" - may serve as a supplement to, but not a central component of, policy rules that deliver good economic performance. Because a net-lending target is very close to a change-in-debt target, as I argued in section 5.4, Phillips' argument is that such a target is likely to deliver unstable outcomes for government debt. ${ }^{21}$

Like Switzerland, Sweden stands out among advanced economies by experiencing declining or flat government debt-GDP ratios in the wake of the global financial crisis. After peaking at close to 75 percent during Sweden's banking and debt crisis in the early 1990s, central government debt has fallen steadily [figure 5]. It was about 35 percent when the global financial crisis hit in 2008 and is now around 30 percent. This has occurred during a period in which government debt in nearly every other country expanded rapidly and, in most cases, has remained elevated almost a decade after the crisis began.

At one level, this remarkable stability in government debt underscores the success of the Swedish fiscal policy framework. At the same time that debt has declined in recent years, many nominal bond yields have been negative, as section 4 documents. As I argued in that section, Swedish governments have declined the bond market's offer of a free lunch, which presents an opportunity to raise welfare among Swedes. Perhaps this is a sign of an overly-rigid desire to reduce government debt, regardless of prevailing economic conditions.

Government bond developments in figure 5 are reflected in net-lending data. Figure 6 plots net lending as a percentage of GDP, along with the net-lending target, which was 2 percent of GDP until it was reduced to 1 percent in 2007. Most notable in this figure is the sharp increase in net lending over the past few years. In the process of refusing the free lunch, the government actually chose to reduce its borrowing when the bond market was willing to pay for the privilege to lend.

\section{Some Estimates from Swedish Data}

Can we find support in Swedish data for the fiscal policy actions that underlie the net-lending target? This section turns to some estimates of Swedish fiscal policy behavior to address that question.

\footnotetext{
${ }^{21}$ By Phillips's reasoning, a proportional rule that is more stable than those underlying either the netlending or change-in-debt targets would simply make surpluses depend on deviations of debt from some target debt-GDP ratio, $b^{*}$. Such a rule would be $s_{t}-\bar{s}=\gamma\left(b_{t-1}-b^{*}\right)$ with $\gamma>\beta^{-1}-1$. This restriction on $\gamma$ instructs the government to raise surpluses with debt by enough to cover the increase in real interest payments plus some amount to return debt to target.
} 


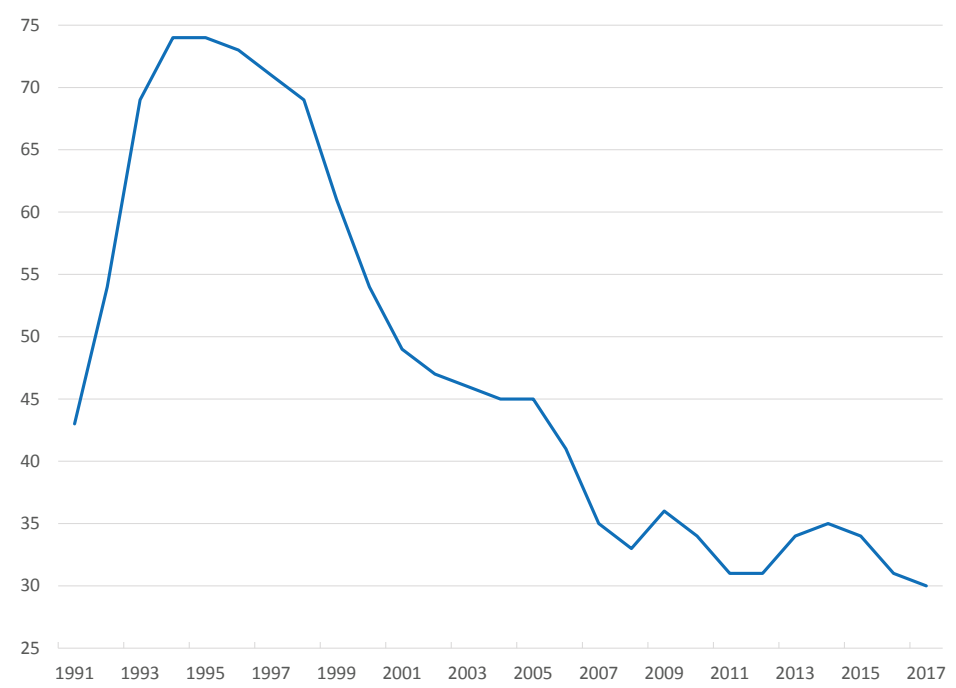

Figure 5: Swedish central government debt as a percentage of GDP, annual data. Source: Riksgälden Swedish National Debt Office, Debt Statistics.

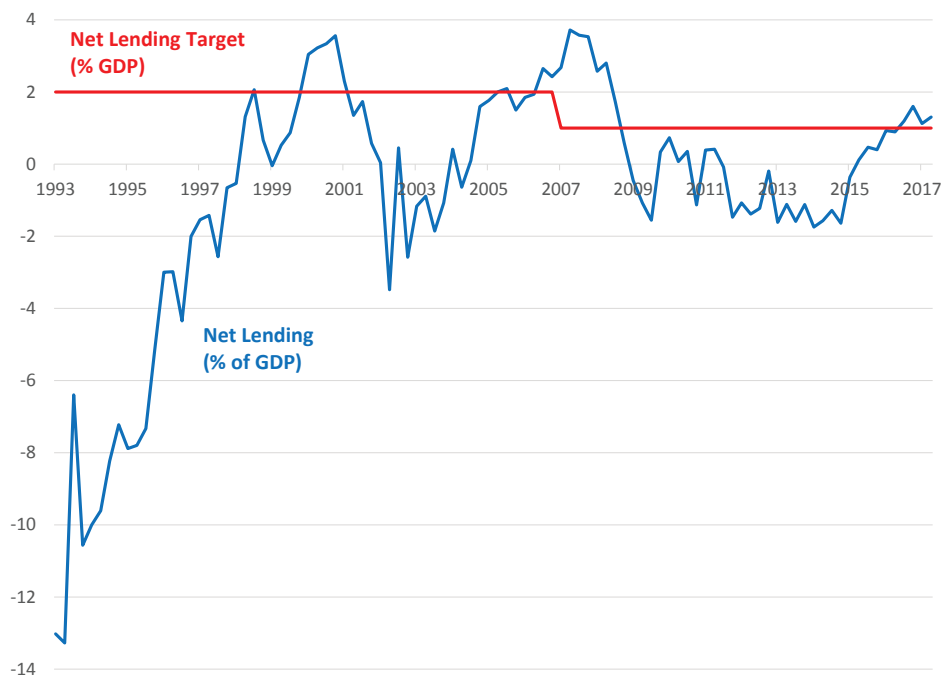

Figure 6: Swedish government net lending as a percentage of GDP, quarterly data. Source: Swedish National Debt Office, Debt Statistics.

\subsection{Estimates of Net-Lending Rule}

As a first pass at applying this theoretical reasoning to Swedish data, I estimate versions of the fiscal rule in expression (4), which adjusts the primary surplus to target net lending. Table 5 reports estimates of fiscal behavior using quarterly data from 1993 through the first half of 2017.

These estimates do not lend support to the hypothesis that Swedish fiscal policy adjusts primary surpluses to target net lending, as fiscal rule (4) posits. Negative values of the 
thresholds in table 3 give the minimum response of surpluses to net lending - the $\gamma$ coefficient in the rule - that stabilizes government debt. To return net lending to target, surpluses must move in the opposite direction of net lending's deviation from target: if net lending is too high, surpluses must be reduced. Taken at face value, the estimates in the first three columns of table 5 report that when net lending is high, the government raises surpluses. This reaction does not appear to be consistent with a net-lending target because it makes net lending increase to deviate farther from target. This pattern holds in both the ordinary least squares and the instrumental variables panels. The instrumental variables estimates aim to address the fact that the ordinary least squares estimates are contaminated by the naturally positive relationship between net lending and the primary surplus that the government's budget identity delivers.

The fourth columns in the two panels seem more promising. That specification alters fiscal rule (4) by making surpluses react to lags in both net lending and in surpluses, a specification that smooths the fiscal response over time. Although the coefficient on lagged net lending is negative, as stabilizing behavior requires, it is not statistically different from 0 . The long-run response of surpluses to net lending takes account of how current surpluses depend on past surpluses, a dependence that raises the response well above the estimate of 0.107 reported as the coefficient on lagged net lending. But because that coefficient is not statistically significant, it is difficult to conclude there is strong evidence that fiscal policy follows the net-lending rule in equation $(4) .^{22}$

The fourth column of the instrumental variables panel reports a somewhat more significant coefficient on lagged net lending. Unfortunately, the estimate on lagged surpluses implies that the equation is not stable, with surpluses exploding over time. This economically nonsensical estimate makes it hard to take the equation seriously as a description of fiscal policy behavior.

An important shortcoming of the regressions that table 5 reports is that they do not indicate how primary surpluses and net lending interact dynamically. Although the simple theory above makes surpluses respond immediately to higher net lending, in practice there is no reason to expect such instantaneous reaction. To explore the dynamic interactions, we estimate a two-variable vector autoregression (VAR) with the primary surplus and net lending, both measured as shares of GDP. ${ }^{23}$ VAR estimates generalize the regression in the fourth column of table 5 in two ways. First, it permits surpluses to respond to current

\footnotetext{
${ }^{22}$ In the regression $s_{t}=\rho s_{t-1}+\gamma\left(n_{t-1}-n^{*}\right)+\bar{s}$, the long-run response of surpluses to past net lending is $+\gamma /(1-\rho)$, where in table $5, \rho$ is estimated to be 0.979 .

${ }^{23}$ The VAR employs the Bayesian methods in Sims and Zha (1998). In their notation, the prior sets $\lambda_{1}=1.0, \lambda_{2}=0.5, \lambda_{3}=1.0, \lambda_{4}=0.1, \mu_{5}=1.0, \mu_{6}=1.0$. The VAR includes four lags and a constant term in each equation and was estimated over the period 1993Q1 to 2017Q2.
} 
Dependent Variable $s_{t}$

\begin{tabular}{|c|c|c|c|c|}
\hline \multicolumn{5}{|c|}{ Ordinary Least Squares } \\
\hline$n_{t}$ & $\begin{array}{l}0.974^{\text {*** }} \\
(0.028)\end{array}$ & & $\begin{array}{c}0.597^{* * *} \\
(0.059)\end{array}$ & \\
\hline$n_{t-1}$ & & $\begin{array}{l}0.848^{* * *} \\
(0.043)\end{array}$ & & $\begin{array}{l}-0.107 \\
(0.123)\end{array}$ \\
\hline$s_{t-1}$ & & & $\begin{array}{l}0.372^{* * *} \\
(0.055)\end{array}$ & $\begin{array}{l}0.979^{* * *} \\
(0.121)\end{array}$ \\
\hline const & $\begin{array}{l}0.276^{* * *} \\
(0.101)\end{array}$ & $\begin{array}{l}0.321^{* *} \\
(0.155)\end{array}$ & $\begin{array}{l}0.224^{* * *} \\
(0.101)\end{array}$ & $\begin{array}{c}0.043 \\
(0.125) \\
\end{array}$ \\
\hline \multicolumn{5}{|c|}{ Instrumental Variables } \\
\hline$n_{t}$ & $\begin{array}{l}0.921^{* * *} \\
(0.045)\end{array}$ & & $\begin{array}{c}0.046 \\
(0.108)\end{array}$ & \\
\hline$n_{t-1}$ & & $\begin{array}{l}0.788^{* * *} \\
(0.052)\end{array}$ & & $\begin{array}{l}-0.182^{*} \\
(0.099)\end{array}$ \\
\hline$s_{t-1}$ & & & $\begin{array}{l}0.854^{* * *} \\
(0.099)\end{array}$ & $\begin{array}{l}1.073^{* * *} \\
(0.103)\end{array}$ \\
\hline const & $\begin{array}{l}0.308^{* * *} \\
(0.101)\end{array}$ & $\begin{array}{l}0.374^{* * *} \\
(0.133)\end{array}$ & $\begin{array}{c}0.111 \\
(0.086)\end{array}$ & $\begin{array}{c}0.042 \\
(0.091)\end{array}$ \\
\hline
\end{tabular}

Table 5: Estimates of $\gamma$ in expression (4). Dependent variable is primary surplus, $s_{t}$, as percentage of GDP. Independent variables are $n_{t}$, net lending as percentage of GDP and $g_{t}$, real GDP growth. Sample for least squares is 1993Q1 to 2017Q2 and for IV is 1994Q4 to 2017Q2. Standard errors in parentheses. Instruments are two lags each of revenues to GDP, government expenditures to GDP, nominal GDP growth, CPI inflation, and the repo rate. Significance levels: ${ }^{* * *}(1 \%),{ }^{* *}(5 \%),{ }^{*}(10 \%)$.

net lending plus four lags of net lending and surpluses. Second, it models net lending as depending on lags of surpluses and net lending, so the VAR tracks net lending's evolution over time.

Figure 7 reports how net lending and primary surpluses are correlated with each other over time. Solid lines are point estimates and dashed lines are 90 percent probability bands. The left panel of the figure shows that when net lending rises, primary surpluses also rise, remaining high for about three years. There is some evidence that eventually surpluses begin to fall, as fiscal rule (4) calls for, but even after 10 years the decline in surpluses is not likely to be different from zero. The right panel looks very much like the dynamics that the government budget identity triggers: higher surpluses raise net lending for some period.

As with the static regressions in table 5 , the dynamic patterns in figure 7 do not support the notion that the Swedish government has systematically followed a rule that reduces primary surpluses whenever net lending is above target. 

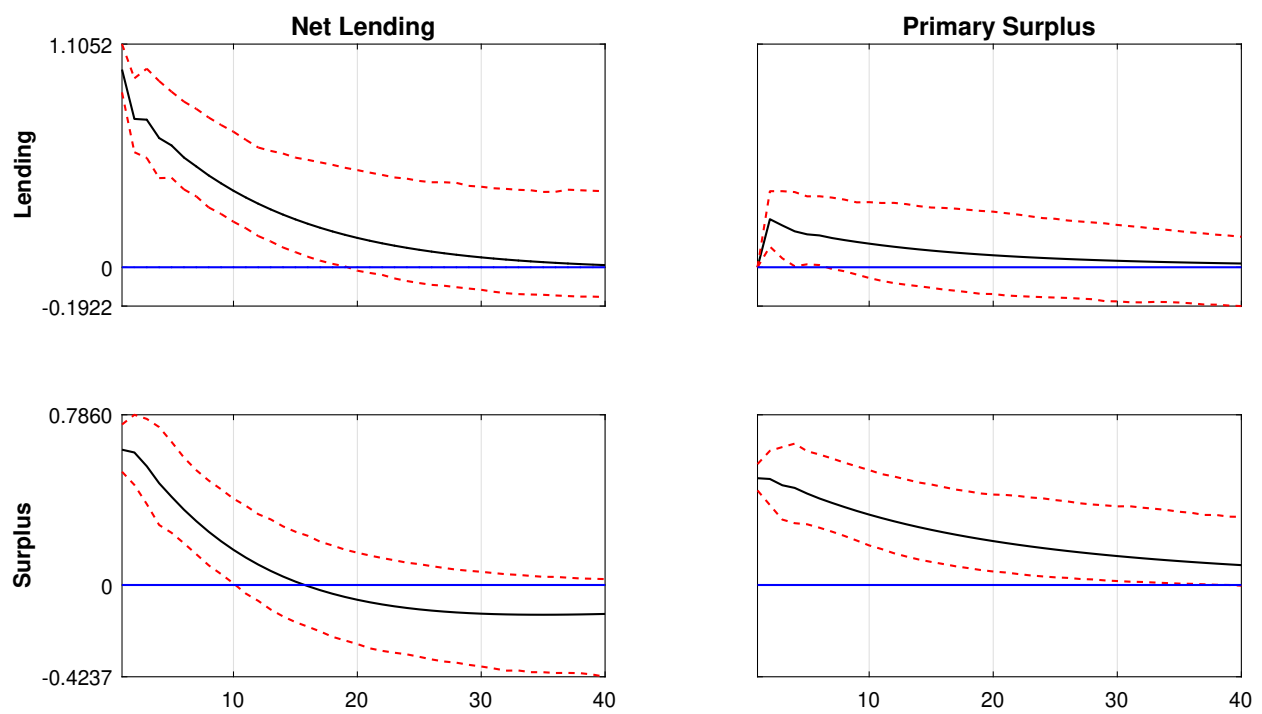

Figure 7: Dynamic responses to shocks in net lending and primary surpluses as percentages of GDP. Horizontal labels are quarters. Dashed lines are 90 percent probability bands.

\subsection{Response of Surpluses to Debt Service}

A central theme of the monetary-fiscal policy interactions that section 2 lays out is that for the central bank to successfully target inflation, fiscal policy must react in particular ways. Whenever monetary policy actions raise (lower) debt service, fiscal policy must eventually respond by raising (lowering) primary surpluses. This is the pattern of response that the alternative representation of fiscal behavior in equation (7) reflects. We now turn to Swedish data to seek evidence of this behavior.

Table 6 reports estimates of variants on equation (7), which depicts how surpluses react to debt service. As with the estimates in table 5, these results must be interpreted cautiously. The government's budget identity induces a positive relationship between the primary surplus and interest payments on the debt. To see this, write the identity in (2) as

$$
b_{t}+s_{t}=\left(\frac{1+R_{t}}{1+G_{t}}\right) b_{t-1}
$$

On the right side of this identity are the real principal on the debt-GDP ratio, $\frac{1}{1+G_{t}} b_{t-1}$, and the real interest payments on that ratio, $\frac{R_{t}}{1+G_{t}} b_{t-1}$. The identity says that when interest payments rise, they must be financed by either higher surpluses, $s_{t}$, or more debt issuance, $b_{t}$. But this relationship stems from an accounting fact, not from any explicit policy behavior, which is the object of our interest. 
Dependent Variable $s_{t}$

\begin{tabular}{|c|c|c|c|c|}
\hline \multicolumn{5}{|c|}{ Ordinary Least Squares } \\
\hline$\overline{r_{t} b_{t-1}}$ & $\begin{array}{c}0.649^{*} \\
(0.373)\end{array}$ & & $\begin{array}{c}0.183 \\
(0.120)\end{array}$ & \\
\hline$r_{t-1} b_{t-2}$ & & $\begin{array}{c}0.687^{*} \\
(0.348)\end{array}$ & & $\begin{array}{c}0.107 \\
(0.123)\end{array}$ \\
\hline$s_{t-1}$ & & & $\begin{array}{l}0.871^{* * *} \\
(0.032)\end{array}$ & $\begin{array}{l}0.872^{\text {*** }} \\
(0.033)\end{array}$ \\
\hline const & $\begin{array}{c}-0.733^{*} \\
(0.376)\end{array}$ & $\begin{array}{l}-0.618^{*} \\
(0.353) \\
\end{array}$ & $\begin{array}{c}0.019 \\
(0.123) \\
\end{array}$ & $\begin{array}{c}0.043 \\
(0.125) \\
\end{array}$ \\
\hline \multicolumn{5}{|c|}{ Instrumental Variables } \\
\hline$\overline{r_{t} b_{t-1}}$ & $\begin{array}{c}0.408 \\
(0.301)\end{array}$ & & $\begin{array}{c}0.175^{*} \\
(0.102)\end{array}$ & \\
\hline$r_{t-1} b_{t-2}$ & & $\begin{array}{c}0.308 \\
(0.290)\end{array}$ & & $\begin{array}{c}0.182^{*} \\
(0.099)\end{array}$ \\
\hline$s_{t-1}$ & & & $\begin{array}{l}0.889^{* * *} \\
(0.034)\end{array}$ & $\begin{array}{l}0.891^{* * *} \\
(0.034)\end{array}$ \\
\hline const & $\begin{array}{c}0.067 \\
(0.267)\end{array}$ & $\begin{array}{c}0.094 \\
(0.266)\end{array}$ & $\begin{array}{c}0.047 \\
(0.090)\end{array}$ & $\begin{array}{c}0.042 \\
(0.091)\end{array}$ \\
\hline
\end{tabular}

Table 6: Estimates of $\frac{\gamma}{1+\gamma}$ in expression (7). Dependent variable is primary surplus, $s_{t}$, as percentage of GDP. Independent variables are $r_{t} b_{t-1}$, net interest payments in period $t$ and $r_{t-1} b_{t-2}$, net interest payments in period $t-1$. Sample for least squares is 1993Q1 to 2017Q2 and for IV is 1994Q4 to 2017Q2. Standard errors in parentheses. Instruments are two lags each of revenues to GDP, government expenditures to GDP, nominal GDP growth, CPI inflation, and the repo rate. Significance levels: ${ }^{* *}(1 \%),{ }^{* *}(5 \%),{ }^{*}(10 \%)$.

With this cautionary note in mind, we turn to table 6 . Although all the estimated coefficients on debt service, either $r_{t} b_{t-1}$ or $r_{t-1} b_{t-2}$, are positive, none are statistically different from zero. This includes both the least squares and the instrumental variables estimates and specifications with and without lagged surpluses. Despite the positive correlation that the budget identity imposes, these regressions do not provide strong evidence that higher debt service leads to higher surpluses, as passive fiscal behavior in the conventional policy regime requires.

Figure 8 reports dynamic correlations between primary surpluses and debt service from a VAR that includes those variables. With a two-year lag, higher debt service is followed by higher surpluses (first column of figure). The second column shows that higher surpluses are followed by lower interest payments, as expected if surpluses are used to retire outstanding debt.

Whether these estimates recover fiscal behavior or merely reflect fiscal dynamics created by the government's budget identity is an open question. The evidence is, at best, merely 

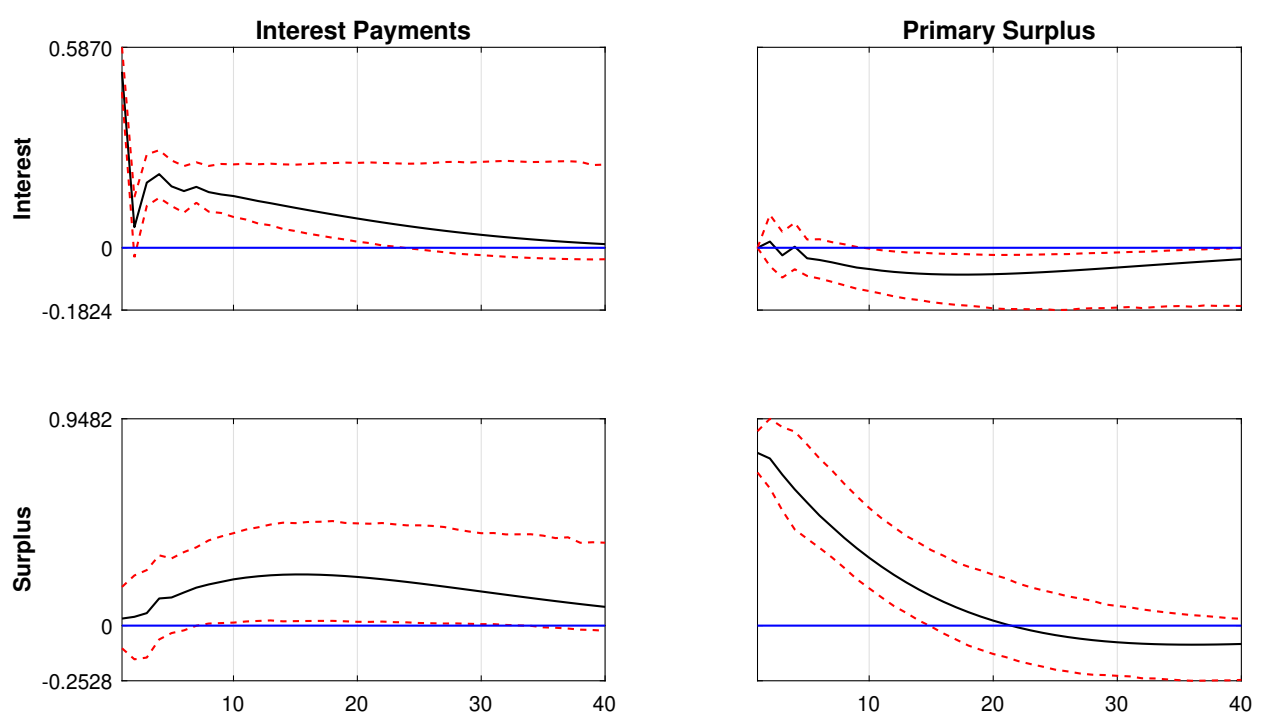

Figure 8: Dynamic responses to shocks in net interest payments and primary surpluses as percentages of GDP. Dashed lines are 90 percent probability bands.

suggestive of how Swedish fiscal policy has behaved. The estimates are crude because they do not account for the fact that variables in the regressions may be determined simultaneously. Leeper and $\mathrm{Li}$ (2016) point out, for example, that regressions of surpluses on past debtor, as in table 6, interest payments on debt - can be seriously biased, depending on which monetary-fiscal regime prevailed over the sample. Less crude estimates would entail jointly estimating policy behavior and private sector behavior as a means of identifying the fiscal rule. Work of this sort ought to be routine in any country that seeks to follow a well-specified fiscal target.

\section{Subtle Ways That Monetary Policy Affects Fiscal Policy}

Government debt is like any other asset: its value depends on discounted expected cash flows. Cash flows associated with government debt are real primary surpluses - the excess of revenues over expenditures, not including net interest payments on outstanding debt. Primary surpluses are debt's cash flows because they provide the real future payments that back government debt. Real interest rates determine the rate at which surpluses are discounted.

\subsection{Demand For Government Bonds}

Debt valuation can be understood using basic supply and demand analysis in the bond market. Start from the government budget identity above, which I repeat here, slightly 
rewritten by dividing through by the price level to convert debt and surpluses from krona into real units of goods

$$
\frac{Q_{t} B_{t}}{P_{t}}+s_{t}=\frac{\left(1+\rho Q_{t}\right) B_{t-1}}{P_{t}}
$$

We want to know the value of debt outstanding at the beginning of the current period, period $t$, which is $\frac{\left(1+\rho Q_{t}\right) B_{t-1}}{P_{t}}$. Already from the left side of this identity, we see that the higher is the current real primary surplus, $s_{t}$, the higher is the value of inherited debt (holding fixed the value of newly issued debt). But this identity implies the value of outstanding debt depends on all future primary surpluses as well, which leads to the debt-valuation equation ${ }^{24}$

$$
\frac{\left(1+\rho Q_{t}\right) B_{t-1}}{P_{t}}=E_{t} \sum_{T=t}^{\infty} q_{t, T} s_{T}
$$

Using this expression in the budget identity in (8) yields

$$
\frac{Q_{t} B_{t}}{P_{t}}=E_{t} \sum_{T=t+1}^{\infty} q_{t, T} s_{T}
$$

This expression says that the value of debt sold in period $t$ equals the expected $\left(E_{t}\right)$ sum of future discounted real primary surpluses beginning in period $t+1$. The variables $q_{t, T}$ are real discount factors, which are products of all future one-period real interest rates between periods $t$ and $T$, inverted. Suppose the one-period real interest rate between periods $t$ and $t+1$ is $1+r_{t+1}$, then the one-period discount factor between those periods is $1 /\left(1+r_{t+1}\right)$. The two-period discount factor between periods $t$ and $t+2, q_{t, t+2}$, is simply $\frac{1}{1+r_{t+1}} \frac{1}{1+r_{t+2}}$, and so on.

The real interest rate is an intertemporal price. Today's real rate, $1+r_{t+1}$, is the price of goods today expressed in terms of future goods, so a lower real rate corresponds to goods today being relatively cheap. In economic models of the sort that many central banks employ, the real interest rate is the linchpin for the transmission of monetary policy: when the central bank reduces nominal interest rates, real rates also tend to fall, inducing people to substitute away from demanding goods in the future toward demanding goods today. But expression (9) reveals another channel through which real interest rates affect the economy. The real discount factors in this debt-valuation equation express goods in the future (primary surpluses) in terms of goods today to deliver the value of current debt in units of current goods $\left(Q_{t} B_{t} / P_{t}\right)$. A lower path for real interest rates raises the value of future goods relative to current goods, which increases the real backing - the present value of surpluses-and,

\footnotetext{
${ }^{24}$ Dependence on the entire future arises because the budget identity holds for all dates $t$ in the future, so the value of debt issued at $t, B_{t}$, rises with surpluses the next period, $s_{t+1}$, and so on through time.
} 
therefore, the value of debt.

The important point is that discount factors multiply - and therefore compound - interest rates. If the real interest rate is low today - for example, if $r_{t+1}$ is negative - then that low rate affects all future discount factors and can have a large impact on the present value of surpluses and thereby on the value of outstanding debt. This creates an important channel through which monetary policy actions can have fiscal consequences. More persistent and larger changes in the monetary policy interest rate will translate into bigger fiscal impacts.

Valuation equation (9) emerges from interactions between supply and demand for government bonds and, as such, it is a condition that holds in equilibrium. Demand for government bonds, like demand for other saving devices, is the mirror image of demand for goods and services: the stronger is the desire to save by accumulating assets, the weaker is the desire to consume by buying goods and services. When the present value of debt's cash flows - primary surpluses - is high, debt becomes more attractive and people substitute out of buying goods into buying bonds. This reduces aggregate demand. Bond prices may rise and/or the overall level of prices in the economy may fall. As the valuation equation makes clear, the present value of debt's cash flows can rise because people expect higher primary surpluses - through higher taxes or lower expenditures - or because people expect higher discount factors (that is, lower real interest rates).

When bond supply is inelastic, expression (9) delivers the demand for nominal bonds in date $t$, which may be written as

$$
B_{t}^{d}=\frac{1}{Q_{t}} P_{t} E_{t} P V\left(\mathcal{S}_{t+1}\right)
$$

This demand is readily understood. Demand declines with the price, $Q_{t}$, of bonds, so in a graph with the price of bonds on the vertical axis, the demand for bonds is downward sloping, like most demand curves. Because bondholders care about the real value of the bonds they hold, $B_{t}^{d} / P_{t}$, demand for nominal bonds is homogeneous of degree one in the price level, just as it is for any nominal asset, such as money. Bond demand also rises with the real backing for government debt, the expected present value of primary surpluses, denoted by $E_{t} P V\left(\mathcal{S}_{t+1}\right)$, because higher real backing raises the expected stream of payouts to bond holders.

Figure 9 plots supply and demand for government bonds when the aggregate price level is on the vertical axis. Vertical supply means bonds are supplied perfectly inelastically. The initial equilibrium price level is $P_{1}$ when the demand schedule is $B_{1}^{d}$. A lower bond price, lower expected path of real interest rates (or higher expected path of discount factors), or a higher expected path of primary surpluses pivots demand to the dashed schedule $B_{2}^{d}$. At 
this new demand curve, bondholders wish to hold more bonds at any given aggregate price level, so at price level $P_{1}$ there is an excess demand for bonds. With an inelastic supply of bonds, the price level must fall to eliminate the excess demand for nominal bonds. A lower price level increases the real market value of debt.

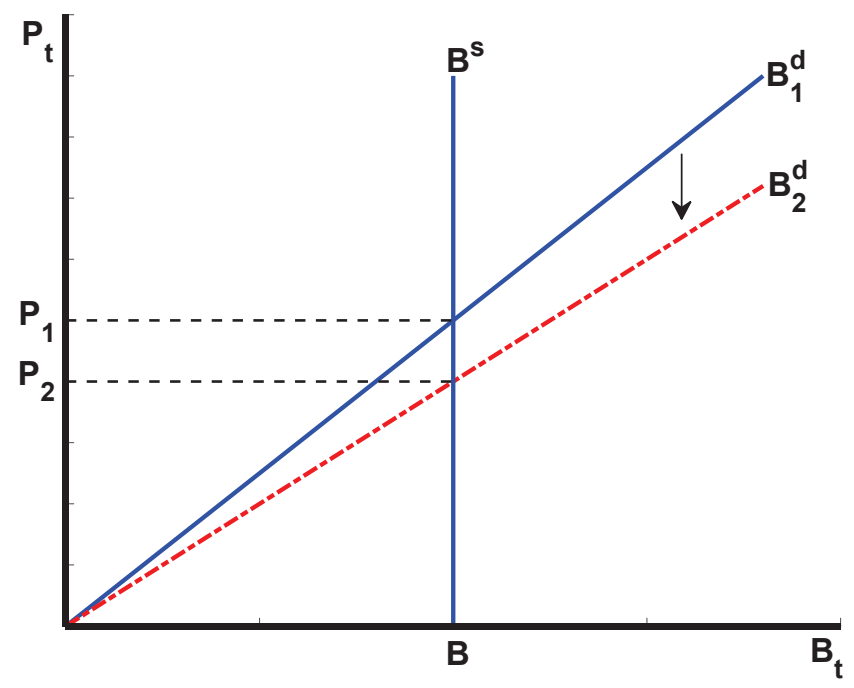

Figure 9: Bond market equilibrium: Supply, $B^{s}$, is inelastic and demand is $B_{t}^{d}=$ $\left(P_{t} / Q_{t}\right) E_{t} P V\left(\mathcal{S}_{t+1}\right)$.

This reasoning can be understood in terms of the impacts on aggregate demand. An increase in demand for bonds is the mirror image of a decrease in demand for goods and services. When government bonds become more desirable, people reduce their purchases of goods and services in order to increase their bond holdings. That decrease in goods demand is a decline in aggregate demand, which drives down the price level, as figure 9 depicts.

\subsection{Applying This Reasoning to Sweden}

How is any of this relevant for Sweden? Section 4 reviewed that Swedish government bond yields have now been negative for more than two years. At times, those negative yields have applied to bonds that do not come due for five years. Table 7 reports a variety of measures of short-term real interest rates in Sweden over three recent periods. Since January 2008, nearly all measures have been negative on average. But over the past two and a half years, the measures have been strongly negative, well over -1.50 percent in some cases. In contrast, over the seven years before the financial crisis, real interest rates were around positive 1.50 percent. Evidently, Sweden is entrenched in a low-interest rate environment.

Low interest rates have been a worldwide phenomenon in recent years. But one clear reason that Swedish real rates have turned sharply negative is the Riksbank's policy stance, a 
stance that includes negative policy interest rates. Because negative real interest rates imply real discount factors greater than 1 , negative rates have important fiscal consequences. Those consequences can be understood through the lens of the debt valuation equation in (9) and the supply-demand graph in figure 9.

\begin{tabular}{|ccr|}
\hline \multicolumn{3}{|c|}{ Average Real Interest Rates } \\
\hline Jan 2001-Dec 2007 & Repo & 3-month Treasury \\
CPI & 1.41 & \\
CPI-F & 1.22 & 1.46 \\
Core CPI & 1.56 & 1.29 \\
Jan 2001-Aug 2017 & & 1.63 \\
CPI & 0.55 & 0.75 \\
CPI-F & 0.23 & 0.44 \\
Core CPI & 0.40 & 0.60 \\
Jan 2008-Aug 2017 & & 0.23 \\
CPI & -0.08 & -0.19 \\
CPI-F & -0.48 & -0.16 \\
Core CPI & -0.45 & \\
Jan 2015-Aug 2017 & & -0.94 \\
CPI & -1.26 & -1.48 \\
CPI-F & -1.79 & -1.54 \\
Core CPI & -1.85 & \\
\hline
\end{tabular}

Table 7: Real interest rates are computed as the nominal interest rate in the current month minus the actual inflation rate in the future. For the repo rate, future inflation is next month's rate. For the 3-month Treasury rate, future inflation is the average of the next three months. Real rates computed using the 3-month Treasury end in June 2017. The 3month rate is estimated by the Riksbank using zero-coupon bond yields and a term structure model. Source: Sveriges Riksbank and Swedish National Statistical Office.

Monetary policy actions are closely linked to bond prices: as interest rates decline, bond prices and the nominal value of outstanding debt rise. Figure 10 plots the "price" of government bonds (left axis) against the repo rate (right axis). The "price" of bonds is calculated as the ratio of the market value of government bonds to the par value and is a measure of the $Q_{t}$ variable that appears in the equations. ${ }^{25}$ There is a clear negative relationship between bond prices and the Riksbank's policy interest rate, just as theory would predict. Focusing on the last few years, bond prices rose sharply as the repo rate headed toward negative territory. Since the repo rate turned negative, bond prices have remained elevated.

Negative real interest rates, as in table 7 , beget high real discount rates. Holding the expected path of primary surpluses fixed, higher discount rates raise the current value of

\footnotetext{
${ }^{25}$ This is an approximation to the krona price of the government's outstanding bond portfolio.
} 


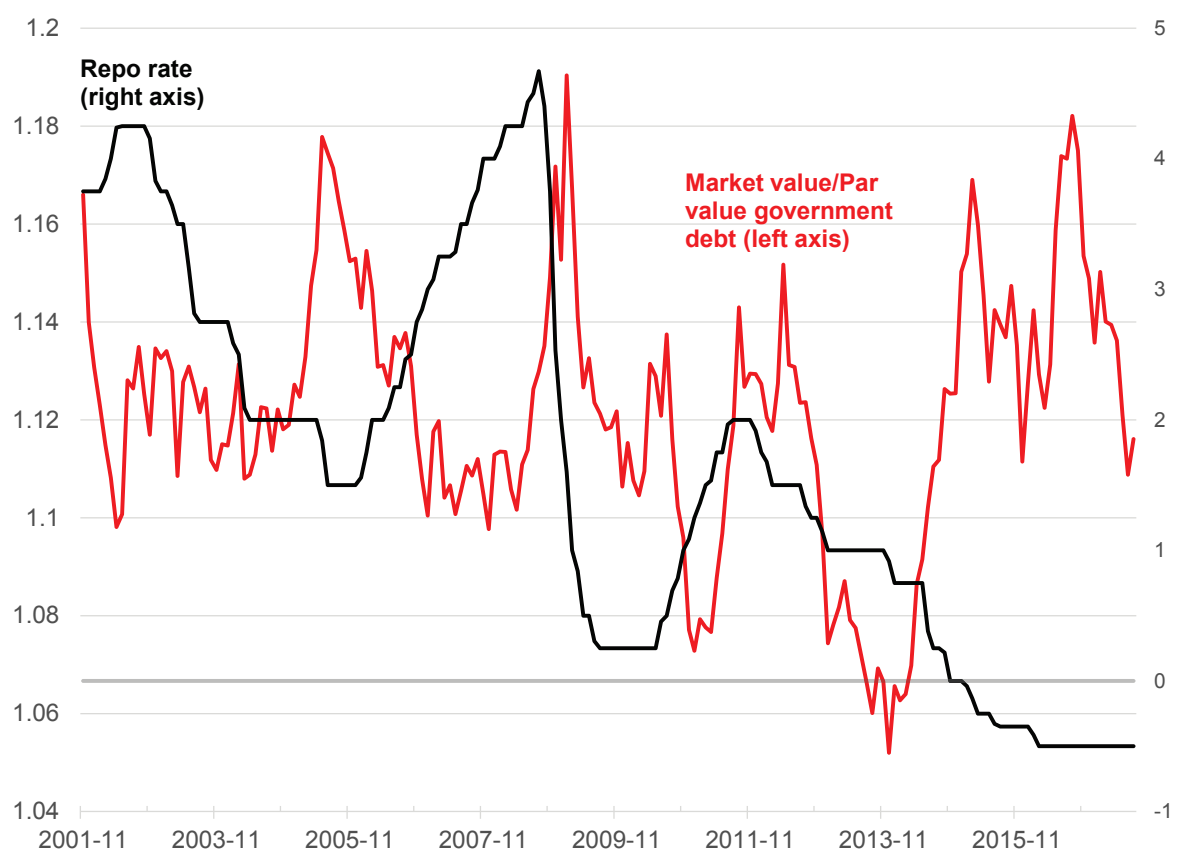

Figure 10: "Price" of government bonds (left axis) and the repo rate (right axis).

those surpluses to shift out the demand for government bonds, as figure 9 depicts. As people substitute out of buying goods and services and into buying bonds, the aggregate price level declines, either now or in the future.

Through the debt-valuation relation alone, lower real interest rates exert deflationary pressures on the economy. Deflationary pressures work against the Riksbank's aim to use negative policy interest rates to raise inflation. To support the Riksbank's actions, fiscal policy can eliminate deflationary pressures by making government bonds less desirable. Bonds lose their appeal when their real backing - future primary surpluses-declines. In terms of figure 9, a lower path for surpluses would offset the effects of lower real interest rates to pivot the $B_{2}^{d}$ demand schedule left toward its initial position, $B_{1}^{d}$.

Swedish fiscal policy during the negative policy interest rate period has not aimed to offset the impacts of low interest rates on the desirability of government debt. Instead, net lending as a percentage of GDP has moved from -1.6 percent in 2014 to 1.2 percent over 2016 and the first two quarters of 2017. To the extent that this shift in net lending raises the path of surpluses that people expect, this fiscal policy makes government debt still more attractive, amplifying the deflationary pressures.

Recently in Sweden, both monetary and fiscal policy have increased the desirability and value of government bonds. Policies have shifted the demand curve down, as in figure 9, to create deflationary pressures through the bond market. This may help to explain Sweden's chronically low inflation rates. 


\section{CONCluding REMARKS}

The paper has pointed to types of analysis that are not commonly undertaken by either monetary or fiscal authorities, but may shed light on how those policies are affecting the economy. For example, many central banks estimate or calibrate interest-rate rules, which are used in policy analyses to provide information on how actual policy choices compare to some useful benchmarks. To my knowledge, such exercises are not typically conducted as an input to fiscal decisions. As I argued elsewhere, there is much that can be done to improve the quality of fiscal analysis in ministries of finances [Leeper (2011)].

This paper does not deny the value of explicit targets for monetary and fiscal authorities to achieve. It also does not deny the potential value of monetary and fiscal rules. The paper's thesis is that these targets and rules should not be designed in isolation. If monetary and fiscal actions are not mutually consistent in ways that this paper has explained, it may be impossible for the central bank and the government to achieve their objectives.

The paper's examination of Swedish macroeconomic policies raises some concerns about whether fiscal policy is compatible with monetary policy's pursuit of an inflation target. I am concerned that in recent years the desire to hit a 1 percent net-lending target conflicts with the Riksbank's efforts to hit its 2 percent inflation target. Because these two targets and any operational rules for achieving the targets have been chosen independently of each other, the potential for conflict is real. 


\section{REFERENCES}

BAi, Y. And E. M. Leeper (2017): "Fiscal Stabilization vs. Passivity," Economics Letters, 154, 105-108.

Balke, N. And R. J. Gordon (1986): "Appendix B: Historical Data," in The American Business Cycle: Continuity and Change, ed. by R. J. Gordon, Chicago: University of Chicago Press, 781-850.

Bhattarai, S., J. W. Lee, And W. Y. Park (2016): "Policy Regimes, Policy Shifts, and U.S. Business Cycles," Review of Economics and Statistics, 98, 968-983.

Bianchi, F. And C. Ilut (2017): "Monetary/Fiscal Policy Mix and Agents' Beliefs," Review of Economic Dynamics, 26, 113-139.

Bodmer, F. (2006): "The Swiss Debt Brake: How it Works and What Can Go Wrong," Schweizerische Zeitschrift für Volkswirtschaft und Statistik, 142, 307-330.

Clarida, R., J. Galí, and M. Gertler (2000): "Monetary Policy Rules and Macroeconomic Stability: Evidence and Some Theory," Quarterly Journal of Economics, 115, 147-180.

Cochrane, J. H. (1999): "A Frictionless View of U.S. Inflation," in NBER Macroeconomics Annual 1998, ed. by B. S. Bernanke and J. J. Rotemberg, Cambridge, MA: MIT Press, vol. $13,323-384$.

- (2011): "Determinacy and Identification with Taylor Rules," Journal of Political Economy, 119, 565-615.

Danninger, S. (2002): "A New Rule: 'The Swiss Debt Brake', IMF Working Paper $\mathrm{WP} / 02 / 18$, January.

Davig, T. And E. M. Leeper (2006): "Fluctuating Macro Policies and the Fiscal Theory," in NBER Macroeconomics Annual 2006, ed. by D. Acemoglu, K. Rogoff, and M. Woodford, Cambridge: MIT Press, vol. 21, 247-298.

Friedman, M. And A. J. Schwartz (1963): A Monetary History of the United States, 1867-1960, Princeton, NJ: Princeton University Press.

Hall, G. J. And T. J. Sargent (2015): "A History of U.S. Debt Limits," Manuscript, New York University, December 8. 
Jacobson, M. M., E. M. Leeper, And B. Preston (2017): "Recovery of 1933," Manuscript, Indiana University, February.

Jalil, A. J. And G. RuA (2017): "Inflation Expectations in the U.S. in Fall 1933," in Research in Economic History, ed. by S. Wolcott and C. Hanes, Emerald Group Publishing Limited, vol. 33, 139-169.

Johnson, JR., G. G. (1939): The Treasury and Monetary Policy, 1933-1938, New York: Russell \& Russell.

Leeper, E. M. (1991): "Equilibria Under 'Active' and 'Passive' Monetary and Fiscal Policies," Journal of Monetary Economics, 27, 129-147.

(2011): "Monetary Science, Fiscal Alchemy," in Macroeconomic Challenges: The Decade Ahead, 2010 Jackson Hole Symposium: Federal Reserve Bank of Kansas City Economic Conference Proceedings, 361-434.

(2016): "Why Central Banks Should Care About Fiscal Rules," Sveriges Riksbank Economic Review, 3, 109-125.

(2017): "Fiscal Analysis is Darned Hard," in Rethinking Fiscal Policy After the Crisis, ed. by Ludovít Ódor, Cambridge, U.K.: Cambridge University Press, 23-70.

Leeper, E. M. AND C. Leith (2017): "Understanding Inflation as a Joint MonetaryFiscal Phenomenon," in Handbook of Macroeconomics, ed. by J. B. Taylor and H. Uhlig, Amsterdam: Elsevier Press, vol. 2B, 2305-2416.

Leeper, E. M. And B. Li (2016): "On the Bias in Estimates of Fiscal Policy Behavior," Manuscript, Indiana University, October.

Leeper, E. M. And T. B. Walker (2013): "Perceptions and Misperceptions of Fiscal Inflation," in Fiscal Policy After the Financial Crisis, ed. by A. Alesina and F. Giavazzi, Chicago: University of Chicago Press, 255-299.

Leeper, E. M. And X. Zhou (2013): "Inflation's Role in Optimal Monetary-Fiscal Policy," NBER Working Paper No. 19686, November.

Lubik, T. A. And F. Schorfheide (2004): "Testing for Indeterminacy: An Application to U.S. Monetary Policy," American Economic Review, 94, 190-217.

Obstfeld, M. And K. Rogoff (1983): "Speculative Hyperinflations in Maximizing Models: Can We Rule Them Out?" Journal of Political Economy, 91, 675-687. 
Phillips, A. W. (1954): "Stabilisation Policy in a Closed Economy," The Economic Journal, 64, 290-323.

Riksgälden Swedish National Debt Office (2017): "Central Government Debt Management: Proposed Guidelines 2018-2021," Reg. no 2017/781, 29 September.

Romer, C. D. (1992): "What Ended the Great Depression?" Journal of Economic History, $52,757-784$.

Roosevelt, F. D. (1933a): "Fireside Chat," October 22, 1933. Online by Gerhard Peters and John T. Woolley, The American Presidency Project. http: //www . presidency · ucsb . edu/ws/?pid=14537.

- (1933b): "Wireless to the London Conference," July 3, 1933. Online by Gerhard Peters and John T. Woolley, The American Presidency Project. http: //www . presidency · ucsb . edu/ws/?pid=14679.

(1936): “Acceptance Speech for the Renomination for the Presidency," Philadelphia, PA, June 27. Online by Gerhard Peters and John T. Woolley, The American Presidency Project. http://www.presidency . ucsb.edu/ws/?pid=15314.

Schaechter, A., T. Kinda, N. Bundina, And A. Weber (2012): "Fiscal Rules in Response to the Crisis - Toward the 'Next-Generation' Rules. A New Dataset," IMF Working Paper No. WP/12/187, July.

Sims, C. A. (1994): "A Simple Model for Study of the Determination of the Price Level and the Interaction of Monetary and Fiscal Policy," Economic Theory, 4, 381-399.

(2013): "Paper Money," American Economic Review, 103, 563-584.

Sims, C. A. And T. Zha (1998): "Bayesian Methods for Dynamic Multivariate Models," International Economic Review, 39, 949-968.

Sveriges Riksbank (2018): Monetary Policy Report, Stockholm, April: Sveriges Riksbank.

Swedish Government (2011): The Swedish Fiscal Policy Framework, Stockholm: Regeringskansliet.

TAYlor, J. B. (1993): "Discretion versus Policy Rules in Practice," Carnegie-Rochester Conference Series on Public Policy, 39, 195-214. 
_ (1999): "An Historical Analysis of Monetary Policy Rules," in Monetary Policy Rules, ed. by J. B. Taylor, Chicago: University of Chicago Press, 319-341.

Tobin, J. (1980): Asset Accumulation and Economic Activity, Chicago: University of Chicago Press.

Wallace, N. (1981): "A Modigliani-Miller Theorem for Open-Market Operations," American Economic Review, 71, 267-274.

Woodford, M. (1995): "Price-Level Determinacy Without Control of a Monetary Aggregate," Carnegie-Rochester Conference Series on Public Policy, 43, 1-46.

(2003): Interest and Prices: Foundations of a Theory of Monetary Policy, Princeton, NJ: Princeton University Press. 